\title{
VALÓSÁG
}

Educatio 28 (2), pp. 343-369 (2019)

DOI: $10.1556 / 2063.28 .2019 .2 .10$

\section{INTERJÚK A MAGYARORSZÁGI KERESZTÉNY EGYHÁZAK TANÜGYIGAZGATÁSÁRÓL}

A tanügyigazgatásról szóló számunk nem lett volna teljes, ha nem foglalkozunk az egyházi intézmények szakmai és pénzügyi irányításával. Mivel az utóbbi időben több oldalról is kritika érte az egyházi iskolákat a magasabb fejkvóták és az erősebb szelekció miatt, ezekre a témákra külön is kitértünk. Természetesen foglalkoztunk az iskolaátvételekből származó problémákkal és lehetőségekkel, az államtól való függéssel vagy függetlenséggel, a helyi és központi döntések szerepével és azok előkészítésével, a közfeladatok ellátásának és az egyházak missziós tevékenységének összehangolásával.

\section{Interjú Platthy Iván, nyugalmazott egyházügyi címzetes államtitkárral}

Educatio (a továbbiakban E): Elöször beszéljünk egy kicsit a pályafutásáról. Azt olvastam, hogy népmüvelöként végzett, rövid ideig tanitott, de elég hamar bekerült a minisztériumba. Platthy Iván (a továbbiakban PI): Rövidesen megjelenik a könyvem Párbeszéd az emberért - emlékeim az egyházakról és a társadalomról címen. Nem önéletrajz lesz, arról szól, hogy 1989. július 1-től, tehát attól az időponttól kezdve, amikor megszünt az Állami Egyházügyi Hivatal, mi minden történt, milyen emlékeim vannak erről a harminc évről. De kezdjük az alapokkal, ha ez érdekli. Ungvárról menekült a családom Magyarországra 1944-ben. Édesapám ott volt iskolaigazgató. Vissza már nem mehettünk, ott maradt mindenünk. Lekerültünk Baranyába, ott éltünk különböző településeken. Érettségi után elkezdtem dolgozni, hogy megszerezzem a pénzt a továbbtanulásra. Mindenképpen tanító akartam lenni. Baranyai gyerekként vagy Kaposvárra, vagy Bajára jelentkezhettem. Ott megismerkedtem egy Bács-Kiskun megyei, lajosmizsei évfolyamtársnőmmel, és úgy döntöttünk, ha végzünk, együtt maradunk. Aztán az élet úgy hozta, hogy Pest megyébe kerültünk, Táborfalvára, egy tanyasi iskolába. A faluban segítettem a kulturális életet. Közben elvégeztem a Pécsi Tanárképző Főiskolán a rajz szakot. Egy nap megkeresett a járási tanács elnöke azzal, hogy a művelődési osztályon megüresedett az úgynevezett népművelés-felügyelő státusz. Azt mondtam, hogy csak azzal a feltétellel mondok igent, ha heti két napot a településeken tölthetek, hogy megismerhessek mindenkit. Ezenkívül kértem, hogy, mivel közben levelezőn elvégeztem a rajz meg a politechnika szakot, adjanak nekem valahol tanítási lehetőséget is. Megkaptam, amit kértem. Ezt csináltam körülbelül hat évig, amikor a Müvelödésügyi Minisztériumból megkeresték a járási tanácselnököt és engem, hogy szeretnék, ha átkerülnék hozzájuk. A művelődési házak, klubkönyvtárak 
tartoztak egy darabig hozzám. 1974 júniusában kettévált a minisztérium. Külön oktatási és külön kulturális minisztérium jött létre. A Kulturális Minisztériumban a Közművelődési Főosztályon maradtam egy darabig, majd átkértek az akkor alakuló Tanácsi Főosztályra, ahol egészen '78-ig maradtam. 1978-ban felkért a Minisztertanács Tanácsi Hivatal elnöke az ún. Ágazati Koordinációs Főosztály osztályvezetőjének, majd amikor újra összevonták a művelődési tárcákat, sőt a szakképzést is odatették, felkeresett Pozsgay Imre miniszter úr, hogy szervezzem meg a minisztérium és a tanácsok kapcsolatát. Ezt a feladatot láttam el, mint főosztályvezető, egészen Glatz Ferenc miniszterségének időszakáig.

\section{E: Egyházügyi kérdésekkel ekkor már foglalkozott?}

PI: Nem. Az más kérdés, hogy az egyházakkal valamilyen kapcsolatom természetesen volt, de ezek inkább csak olyan személyes kapcsolatok voltak a településeken. Arra kértem minden munkatársamat, hogy szervezzük meg az egyház és az állam kapcsolatának nulláról felépített rendszerét, az egyházakkal közösen. 1989-ben megszűnt az Állami Egyházügyi Hivatal, jogutód nélkül, minden jogszabályát hatályon kívül helyezték, és a Lendvai utcában dolgozó 60 embert elküldték. Ekkor keresett meg Glatz Ferenc miniszter úr, hogy szervezzem meg egy kis létszámú Egyházi Főosztály létrehozásával a mellérendelt viszonyból álló állam és az egyház kapcsolatát. A mellérendelt viszony azt jelentette, hogy az egyház és az állam, mint egyenrangú felek, közösen alakítsák ki a kapcsolataik jogi és gyakorlati rendszerét. Nagyon egyszerü volt az én logikám: mind a kettő az emberek bizalmából létezik, és az emberek szolgálatára hivatott. Miről szólhat tehát a párbeszéd? Természetesen csak az emberről. Ennek a fö felelőse akkor Kulcsár Kálmán igazságügyi miniszter volt. 1989-90-et írunk. Ekkor születik meg „A lelkiismereti és vallásszabadságról, valamint az egyházakról szóló alkotmányerejü törvény”, melyet az Országgyülés 1990. január 24-én fogadott el.

\section{E: Ki volt a törvény mögött, ki volt a szellemi atyja?}

PI: Elsősorban a politikai akarat, mely az alapvető emberi jogokat garantáló törvények szükségessége közül kiemelten kezelte a fenti törvény megalkotását. Amikor megszűnt az Állami Egyházügyi Hivatal, akkor körülbelül huszonöt-harminc egyház, felekezet, vallási közösség müködött Magyarországon. Nekünk az volt a feladatunk, hogy velük együtt alakítsuk ki a jövőt, így a törvényeket is. Megkértük a négy ún. történelmi egyházat, felekezetet, hogy delegáljanak a föosztályunkra a párbeszéd folyamatosságát biztosítandó képviselőket. Paskai bíboros úr két személyt delegált, akik a Római Katolikus és a Görögkatolikus Egyházat képviselték. Nevezetesen Korzenszky Richárd pannonhalmi perjelt, akit jól ismertek a közoktatásban, és Pregun Istvánt, aki nemcsak a nyíregyházi Görögkatolikus Hittudományi Főiskola rektora volt, de 1985 és 1990 között országgyülési képviselő is. Az evangélikusok, a reformátusok és a zsidóság is delegált egy-egy személyt, általában az ún. központi irodájuk vezetőjét, olyanokat tehát, akik pozícióban voltak, és mindenféle ügyben tudták közvetíteni vagy képviselni az egyházuk véleményét. A törvény megfogalmazására Kulcsár Kálmán kapta a feladatot, de természetesen minden egyház véleményét, javaslatát figyelembe véve. Rendszeres találkozások voltak a törvényalkotáskor. A Szentszékkel való diplomáciai kapcsolatok újrafelvételének tárgyalási alapja, illetve garanciája is a fenti törvény tervezete volt, amit 1989 őszén vitt magával Rómába a háromtagú kormánydelegáció, melynek én is tagja voltam. 


\section{E: A kisegybázak nem nehezteltek, hogy kimaradtak ezekböl a megbeszélésekböl?}

PI: Természetesen nem maradhattak ki, csak nem mindegy, hogy hány személy képviseli őket. Összeültem velük annak érdekében, hogy ők hogyan szeretnék az aktuális témákban a folyamatos párbeszéddel járó közremüködésüket. Felmerült egy-egy vallási csoport, mint például szabadegyházak, ortodoxok, keleti vallások stb., által megbízott képviselők delegálása. Azt kérték, hogy én jelöljek ki egy személyt, akit majd, miután megismerik egymást, megbíznak a koordinatív feladatok ellátásával. Egy olyan munkatársamat kértem fel erre, akinek kapcsolatteremtő készségén kívül komoly affinitása is volt erre a feladatra. Ö végigjárta a baptistáktól kezdve az ortodoxokig az összes egyházat, és mindegyiktől megkapta a felhatalmazást. Megfelelő személynek tartották arra, hogy rajta keresztül közvetítsék a véleményüket. Így tehát nem is lehetett semmilyen neheztelés. Az ő közremüködésével a fent említett törvénynek augusztusra elkészült az a változata, amit olasz nyelvre lefordítva vittünk Rómába. Megjegyzem, hogy az ún. kisegyházi referensi feladatokat a megbízott munkatársnőm nyugdíjazásáig több kormányzati ciklusban remekül látta el.

E: Voltak benne vitás kérdések, vagy a szöveggel mindegyik egybáz egyetértett?

PI: Ebben benne volt már mindegyik egyház véleménye. A Szentszékkel való diplomáciai kapcsolatok felvételéhez a korábbi, '64-es megállapodást is vittük, melyet közös megegyezéssel hatályon kívül helyeztünk. A diplomáciai kapcsolatok újrafelvételének az alapja tehát a Magyar Katolikus Egyház teljes szabadságának biztosítása volt, valamint az, hogy ezáltal az Apostoli Szentszék a magyarországi diplomáciai kapcsolatain keresztül partnerként jelenjen meg. A garanciát biztosító törvény tervezetéhez kisebb módosító javaslatokat tettek, de ezek inkább csak formálisak voltak. Ugyanekkor indult meg II. János Pál pápa 1991-i, magyarországi látogatásának az előkészítése, melynek természetes előzményeként a két fél közötti konszolidált kapcsolatok kialakítása volt a cél, ennek rendezésére az 1990. évi IV. törvény megalkotását követően, 1990. február 9-én került sor az Apostoli Szentszék államtitkárának és a Magyar Köztársaság miniszterelnökének aláírásával.

Ekkor olyan törvény született, mely alapján az állam végképp lemond főkegyúri jogáról, tehát a püspökök kinevezése elött nincs egyetértési vagy véleményezési joga, mert a mellérendelt viszonyból adódóan tiszteletben tartják egymás törvényeit. Felmerült, hogy meg kellene várni a választásokat. A tárgyaló delegációnak az volt a véleménye, hogy most megvan a politikai akarat. Így is lett, 1990. január 24-én a Parlament, talán 11 tartózkodással és egy ellenszavazattal, megszavazta a törvényt a lelkiismeretről és vallásszabadságról, valamint az egyházakról. És itt jön a képbe az oktatás. A 19. paragrafusba az került bele, hogy amennyiben az egyházak közfeladatokban vesznek részt, tehát az oktatás, a kultúra, a szociális stb. területeken, akkor azt az állam hogyan finanszírozza. Eredetileg az volt a terv, hogy az egyházak a normatív finanszírozás ötven százalékát kapják. Kidolgoztunk egy módosító javaslatot Pregun István országgyűlési képviselővel közösen, aminek az volt a logikája, hogy ha az Alkotmány biztosítja a tankötelezettséggel együtt járó ingyenes oktatást, akkor nem lehet gyerekeket megkülönböztetni a hovatartozás vagy szabad iskolaválasztás elvéből adódóan. Ezt január 23-án a Parlamentben Pregun István országgyưlési képviselő beterjesztette, illetve szóban is kiegészítette a hitoktatással kapcsolatos javaslatával együtt. Ez jelentette az ún. szektorsemleges finanszírozás kezdetét. Mindegy, hogy ki látja el a közfeladatot, annak a részére kell biztosítani a müködéshez 
szükséges feltételeket az államnak. Sokan a vallás szabad gyakorlásáról szóló, 1895-ös törvényt szerették volna visszahozni, amelyben az ún. kategorizált egyházak szerepeltek. Mi viszont azt mondtuk, hogy ennek nincs értelme, nem lehet kategorizálni az állampolgárokat vallási hovatartozásuk szerint. A javaslatot el is vetették. Sajnos, 2011-től az akkor módosított egyházügyi törvény szerint ez a kategorizálás újra előkerült, ami már nem mellérendelt viszonyt jelent.

\section{E: Az egyházak között soha nem támadt konfliktus, nem érzékelt nézeteltéréseket?}

PI: A négy egyházi ember hetente kétszer összejött, és ez megmaradt a további években is. Változtak persze a személyek, például Zoltai Gusztáv helyét később átvette Schweitzer Gábor a MAZSIHISZ-nél, vagy Karner Ágoston helyét Szemerei Zoltán az evangélikusoknál, de a konstrukció maradt. Folyamatos párbeszéd csak akkor lehetséges, ha gyakran összejövünk személyesen. Emiatt kértem, hogy egy héten legalább két napot töltsenek nálunk, hogy az összegyült kérdéseket együtt megtárgyaljuk. De az is előfordult, hogy az összes egyházat meghívtuk például az adótörvények alkotásának időszakában. Miután megszületett az adótörvény, összehívtam az összes egyházat, és meghívtam az APEH elnökét, Kékesi László elnök urat, hogy segítse a törvény egyházakat érintő részeinek megértését és végrehajtását. Hogy világos legyen számukra, melyik pontnál milyen kötelezettségeik vannak. Ily módon gyakorlatilag egy felkészítést kaptak. Tehát nemcsak a törvénykészítésnél vontuk be az egyházakat, hanem az utógondozásnál is, hogyan kell a törvényt végrehajtani. Sajnos, jelenleg egy jogszabályban sincs olyan paragrafus, vagy csak feltételes módban, hogy az államnak a törvényalkotás időszakában kötelező lenne minden, az egyházakat érintő kérdésben kikérni az egyházak véleményét. Ennek pedig nagyon egyszerű a logikája. Ha például a közoktatási törvényt akarom módosítani, akkor az iskolafenntartó egyházak véleményét, már a koncepció kialakításánál ki kell kérni, mivel az állam már nincs monopolhelyzetben, mint volt 40 évig. Többször javasoltam, hogy meg kellene oldani, hogy jogilag ez egyértelmü legyen. Ehhez három variáció is lehetséges lehetne. Vagy a Felsőházat kellene újra létrehozni. Ez egy társadalmi kontrollt jelentene a politika fölött. Persze, ahhoz meg kell határozni a Felsőház összetételét, például a 13 nemzetiség, az önkormányzati szövetségek, a Tudományos Akadémia stb. és az egyházak megfelelő képviseletét. A megvalósítása azért nem jön létre, mert a politika nem szeretne társadalmi kontrollt. A másik, hogy a jogalkotásról szóló törvénybe bele kellene venni, hogy minden törvény meghozatala elött elözetesen ki kell kérni az összes érintett szerv véleményét, benne az egyházakét is. Ez se valósult meg. Végül az Uniós Alkotmány, illetve a Lisszaboni szerződés azon cikkére hivatkoztam, mely azt írja elő, hogy az Unió rendszeres nyílt párbeszédet kíván folytatni az egyházakkal és egyházi szervezetekkel. Javasoltam, hogy ezt kellene adaptálni Magyarországon. Szili Katalin volt akkor a parlament elnöke. Ô egyetértett a javaslattal, Kiss Elemér, volt kancelláriaminiszter segítségével ki is dolgoztuk ennek a jogi formáját. Az elnök asszony és egy másik képviselő által benyújtott törvénymódosítási javaslatot ugyan mindenki jónak találta, de még napirendre sem került, mert nem mindegy, hogy melyik oldal terjeszti be azt. Az ehhez kapcsolódó végrehajtási utasítás már azt is tartalmazta, hogy a párbeszédet végző szervezet a mindenkori Miniszterelnöki Hivatalban kell, hogy működjön, és ne változzon a különböző kormányok kénye-kedve szerinti kormányzati szervként. Ezt azért javasoltam, mert a Művelődési Minisztériumból '95-ben átkerültem a Miniszterelnöki Hivatalba, ahol egészen más kapcsolatrendszerem volt. A volt egyházi ingatlantulajdonok rendezésének 
végrehajtását eredetileg a törvény tíz évben szabta meg, ami már akkor várhatóan nem valósult volna meg. Ezért a kormányfö az érintett egyházakkal abban állapodott meg, hogy készüljön egy végleges igénylista három kategóriában. Mi az, amit természetben kérnek vissza, és mire. Mi az, amit nem kérnek vissza, de pénzt kérnek, és mit akarnak belőle csinálni. A harmadikba pedig azok az esetek kerülnének, amikor lemondanak az állam javára az ötszázalékos járadék fejében. Egy ilyen hármas lista jött létre 1997-ben. A Katolikus Egyház akkor 1200 ingatlanról mondott le, az ötvenvalahány milliárd volt, akkor az értéke és ennek az ötszázalékos kamata került szabad felhasználásra mind a mai napig. A többi érintett egyház is ennek megfelelően alakította ki igénylistáját és kötött megállapodást a kormánnyal. Ezt az ötletet én Ausztriából hoztam. A személyi jövedelemadó utáni egy százalék pedig az olasz és a spanyol modell magyarított változataként került be az egyház-finanszírozási törvénybe.

\section{E: Ezt is Ön hozta be, vagy másnak az ötlete volt?}

PI: A volt egyházi ingatlanok tulajdoni helyzetének rendezéséről szóló, 1991. évi XXXII. törvény nem vonatkozott az összes egyházra. Az akkori politika emiatt szükségesnek érezte, hogy készüljön el egy egyház-finanszírozási törvény. Ennek a törvénynek az elkészítése a mi feladatunk lett. Azt javasoltam, hogy kérjük ki a pártok véleményét. A Kisgazdapárt például azt javasolta, hogy vissza kellene adni az egyházaknak a földjeiket is, gazdálkodjanak rajtuk. Két-három párt a személyi jövedelemadó egy százalékát javasolta, volt, aki szerint egyszeri összeget kéne kifizetni és gazdálkodjanak vele. Egységes vélemény nem alakult ki. Horn Gyula ekkor azt javasolta, hogy az Országgyúlés Emberi Jogi, Kisebbségi és Vallásügyi Bizottság terjessze be a törvény tervezetét. Tehát ne a kormány, hanem a bizottság vigye a Parlament elé. Ugyanolyan patthelyzetbe jutott ő is. Ebben az időszakban volt, talán 1996 februárjában, hogy Horn Gyulát meghívta az olasz partnere, és a Külügyminisztérium elkészítette azt is, hogy II. János Pál pápával és a Szentszék államtitkárával is találkozzon, tehát egy vatikáni látogatásra is sor kerüljön. Kért tőlünk egy felkészítő anyagot. Össze kellett foglalnunk, hogy az állam az elmúlt hat év alatt a Katolikus Egyházat érintő témákban hova jutott, mit ért el. Ebben leírtuk mindazt, ami pozitív, és mindazt, amin előbb-utóbb változtatni kell. Ilyen például az, hogy az oktatási intézmények finanszírozásánál a normatíva és a tényleges költségek között az olló egyre szélesebbre nyílik. Azt is javasoltam, hogy mielött elutazik a Vatikánba, üljön le egy kötetlen beszélgetésre a Magyar Katolikus Püspöki Konferencia Állandó Bizottságával. $\mathrm{E} z$ az ötlet tetszett neki, és meghívta az érintetteket. Én is részt vettem a megbeszélésen, de előtte a miniszterelnök a tudománypolitikai és egyházpolitikai tanácsadójával és velem egy rövid megbeszélést tartott, hogy az általunk leírtak alapján mi a javaslatunk a felvetésre kerülő gazdasági kérdések megoldására. Azt javasoltam, hogy szerintem egy részleges konkordátummal lehetne ezt az ügyet rendezni, és majd arra ráépíteni a többi egyházakra is kiterjedő törvényeket, mivel egy államközi nemzetközi szerződés egy védőhálót adhat a többi egyháznak is.

\section{E: Mi az, hogy részleges konkordátum?}

PI: Ellentétben a konkordátummal ez csak bizonyos kérdésekről szól, például gazdasági ügyekről szóló megállapodás. Egy államközi szerződés mindig magasabb, mint egy törvény, amelyet bármikor lehet módosítani, azt csak közös megegyezéssel. A Szentszéki megállapodás tervezete 1997. május 15-én került a kormány elé. Hosszas viták 
után elfogadták. Az volt a javaslat, hogy ezen megállapodás minden egyes pontjában lévő lehetőséget, amit a Katolikus Egyház egy nemzetközi szerződés alapján megkap, minden egyházra érvényessé kell tenni. Ennek érdekében módosítani, illetve alkotni kell hat törvényt, a közoktatási, a felsőoktatási, a tulajdonrendezési, a lelkiismereti és vallásszabadságról szóló törvényt és az egyház finanszírozásról szóló törvényt, még az 1998. évi költségvetés kialakítása előtt.

E: Mit szólt a többi egyház? Azt nem sérelmezték, hogy elöször a katolikusokkal állapodnak meg, és azt alkalmazzák rájuk is?

PI: Ezt nem lehetett másképp, ők nem nemzetközi jogalanyok. De ugyanazok a kérdések merültek fel a reformátusoknál és az evangélikusoknál is, hogy ők is normatívából gazdálkodnak, és nem tudnak mit hozzátenni. Amikor a törvény módosításra került, akkor velük is egyeztettünk. Persze azt is bele kellett tenni, hogy ők miröl mondanak le. 1997. december 2-án a Parlament egy csomagban elfogadta ezt a Szentszéki megállapodást és a hat törvényt. 1998. január 1-jén lépett életbe. Természetesen ebben benne volt az is, hogy az állam, és itt már a kormányt kell érteni, köthet a többiekkel is hasonló megállapodást ezek alapján. Így kötött a reformátusokkal, evangélikusokkal, baptistákkal, ortodoxokkal. Később az akkori kormány megemelte a járadékokat azzal az indokkal, hogy a társadalmi szerepvállalásukat azzal ismeri el. Ez az ún. kiegészítő járadék a Szentszékkel kötött megállapodásban nem volt benne. Szóval, ily módon végül is az egyenlő elbírálás elve sérült, amit csak jóval később sikerült a Katolikus Egyháznak érvényesíteni.

\section{E: Ekkor Ön már nem volt a minisztériumban, ugye?}

PI: Nem, akkor már nem, mivel én 1999-től nyugdíjas lettem.

E: Volt valami konfliktusa a nyugdijazását megelözően?

PI: Nem, egyszerüen csak annyi történt, hogy a négy szinten lejjebbre kinevezett utódom a leendő kormányföt elvitte bemutatni a püspököknek, aki ott bejelentette, hogy ő lesz az utódom. Jöttek a telefonok, kérdezték, hogy mit szólok hozzá, volt-e egyeztetés velem, szeretnék, ha az egyházakkal való koordináció azon a szinten maradna, és abban én is részt vehessek. Válaszom az volt, hogy én a saját magam ügyéért soha nem szóltam. Engem mindenhová hívtak, vagy felkértek, én soha nem jelentkeztem, nem is pályáztam egyetlen egy betöltött pozícióra sem.

\section{E: De rosszul esett?}

PI: Nem vagyok politikus, emiatt ez a része a dolognak kevésbé érdekelt. Azóta is foglalkozom a témával, de nem köt semmiféle politikai vagy pártfegyelem. Most is mondom a magamét, azt, hogy hogyan kellene csinálni, és azt, hogy ezt a tíz évig jónak ítélt, és nemzetközileg is megmérettetett és magyar modellként kezelt, koordinatív párbeszédre alapozó tevékenységet tovább kellene vinni, mert ennek van az ország számára is presztízsnövelö hatása. El lehet rontani, de akkor már nincs magyar modell.

\section{E: Miután elkerült a minisztériumból, mit csinált?}

PI: 1999-ben elmentem nyugdíjba, 60 évesen. Szinte abban a pillanatban felkért Pécs megyei jogú város elnöke, meg a Baranya megyei közgyülés elnöke, hogy jöjjek oda ta- 
nácsadónak, önkormányzatok és egyházak kapcsolata témában. Mondván, hogy valamikor ott élt a család, még most is ott él három családtagom, elvállaltam. Tanácsadóként lejártam Pécsre, és próbáltam mindenfélét csinálni, némelyik szerintem sikeres is volt. Konferenciák sorát rendeztem, az ország különböző részeiből jöttek. Ennek, azt lehet mondani, sok jó eredménye volt. Például a nemzetiségek identitásának segítésének kérdésében. Mind a 12 nemzetiség országos önkormányzatok vezetőit, sőt az érintett országok kultúrattaséit, valamint azokat az egyházakat, amelyek érintettek a nemzetiségi identitás segítésében, meghívtam azzal, hogy találjuk ki, hogyan lehetne javítani, erősíteni a nemzeti identitást. Sok jó példa volt már akkor erre. Két példát mondok, mindkettő az oktatással függ össze. Soltvadkerten a német evangélikus nemzetiségi óvoda és általános iskola. Soha nem volt Soltvadkerten ilyen iskola, és az is új volt, hogy egy egyház felel a nemzetiségi és vallási identitás kialakításáért gyerekkorban. De hasonlót csináltak az evangélikusok Tótkomlóson, óvodát, szlovák nyelvoktatással. Ilyen dolgokat csináltam egészen a Medgyessy-kormány megalakulásáig. Akkor meghívott Kiss Elemér kancelláriai miniszter a kabinetjébe tanácsadónak.

\section{E: Szintén egyházi kérdésekkel foglalkozott?}

PI: Egyházi és önkormányzati tanácsadóként dolgoztam. Amikor Kiss Elemér lemondott és Kiss Péter jött helyette, meg Medgyessy is elment, akkor Szili Katalin, az Országgyülés elnöke kért fel egyházügyi tanácsadónak. E feladatomból adódóan folytattam az egyházakkal a párbeszédet, mivel a Gyurcsány-kormány időszakában nem volt igazi párbeszéd, az elnök asszony és a négy egyház vezetőivel való találkozások alkalmával elöjöttek különböző egyedi és általános problémák, melyeket ő természetesen mindig továbbított a kormánynak, mondván, hogy neki abban csak közvetítő szerepe van. Itt is elsősorban a finanszírozás volt a probléma, meg az, hogy hiányolták a jogalkotásban való részuételt.

E: Arra kérném, hogy, ha lehet, mostantól csak a Katolikus Egyházra koncentráljunk. Az evangélikusokkal és a reformátusokkal külön interjú fog készülni. 2010 óta azt látjuk, hogy meredeken emelkedik az egybázi iskolák száma, így a katolikusoké is. Ez, gondolom, új, nagy feladatot jelent. Hogyan oldották meg ezt a katolikusok, hogyan szervezték meg az iskolahálózatuk irányitását, koordinációját?

PI: Ez nem így ment. Az egyházi tulajdonrendezés lezárult, viszont a második Orbánkormány időszakában megtörtént az önkormányzati iskolák államosítása. Ez az államosítás teljesen független volt a tulajdonrendezéstől. Ebben az időszakban egy újságíró kérdésére válaszolva mondtam azt, hogy azok az önkormányzatok, amelyeknek eszük van, odaadják az iskolájukat valamelyik egyháznak, hiszen jogos a félelem, hogy az államosítás következtében eltűnhet majd a falu szellemisége. Az iskolaátadások 99\%-a emiatt történt. Érdekelt a téma, jártam is az egyházmegyékben, és ezt tapasztaltam. Nagyon tisztességesen csinálták ezt egyébként. Például az Egri Egyházmegyében Ternyák Csaba érsek úr csak akkor vett át iskolát, ha az önkormányzat megkereste, és az önkormányzat összehívta a pedagógusokat, szülőket, hogy kiderüljön, tényleg akarják-e, avagy sem. Ugyanígy a Váci Egyházmegyében Beer Miklós püspök úr. Ha meghívásra elmegy az évnyitókra, évzárókra, ahol megjelennek a pedagógusok az összes iskolából. Mit mond ilyenkor az egybegyülteknek? Örülök, hogy itt vannak, lehet, hogy nem azonosulnak az iskola fenntartójának minden elképzelésével, de csak az a lényeg, hogy jó 
pedagógusok legyenek, és szeressék a gyerekeket. Én ezt kérem Önöktől. Ez volt tehát az alap. Megmenteni az iskolát, és az egyház tudta megmenteni, tudta finanszírozni. Miért tudta finanszírozni? Mert ott a kiegészítő normatíva, ami a Szentszéki megállapodás egyik tétele volt. Egy ilyen plusz pénz előteremtésére nagyon sok önkormányzat nem volt képes. Jelenleg a normatív finanszírozás helyett a feladatfinanszírozást hangsúlyozzák. Egy konferencián megkérdeztem az akkori közoktatási helyettes államtitkártól, hogy mit ért feladatfinanszírozáson, hogy néz ki ez a gyakorlatban? Tehát a szakma mondja meg, hogy a tankötelezettséggel járó, ingyenes oktatáshoz mennyi pénz szükséges? Nemigen tudott válaszolni.

E: Váratlanul érhette az egyházakat, hogy egyszerre tömegével jelentkeztek önkormányzatok. Mit tudott lépni erre a Katolikus Egyház? Gondolom, embereket kellett fölvenni, oktatási irodákat létrehozni.

PI: Igen, persze. Náluk egyszerű, mert centralizált a finanszírozás. Egyházmegyék tartják fenn az iskolákat, ebből adódóan tudnak gazdálkodni is. Azt is figyelembe vették, hogy miért kéri az önkormányzat, hogy vegye át az iskoláját. Például egy tiszta cigány iskola esetében Felsőzsolcán.

E: Az átvételröl mindig a püspök döntött?

PI: Igen, ez mindig az egyházmegye főpásztorán múlott, természetesen oktatási szakemberek bevonásával.

E: Mivel magyarázza, hogy eltérő gyakorlatok tapasztalhatók az egyházmegyék között? Az adatokból én azt tapasztaltam, hogy a pécsi keveset vett át, az egri nagyon sokat.

PI: Baranyában és Tolnában Udvardy György püspök úr úgy gondolta, hogy a jelenlegi iskolák elegendőek, ő nem szeretne többet. A ferencesek nem igazán akartak többet, de megszólították őket. Ma olyan intézménynek is a fenntartói, gondolok például Jászberényre, amelyben hiányszakmák képzése folyik. Tehát nem is gimnázium. Vagy például a piaristák Gödön szintén szakképzést csinálnak. A piaristák iskolafenntartó profilja is változott egy kicsit. Ez mindig az igény szerint, a társadalmi kihívásoknak megfelelően történik. Szerzetesek esetében ez persze nem könnyü, hisz ott szükséges, hogy legalább egy vagy két szerzetes legyen az iskola lelki vezetője. A Katolikus Egyház esetében ott a plébános, de az igazi felelős az adott egyházmegye első számú embere. Minden egyházmegyében létrehoztak egy EKIF-et (Egyházmegyei Katolikus Iskolák Főhatóságát).

\section{E: Ez hasonló, mint ami az állami szektorban van?}

PI: Igen, ugyanúgy van pedagógiai intézetük, a Püspökkari Konferencia által működtetett Pedagógiai Intézet, mely összefogja a római és a görögkatolikus iskolafenntartók oktatási szakértőit.

\section{E: Hány emberröl van szó?}

PI: Ezt pontosan nem tudom, de szerintem egy-egy püspökségen, közoktatási intézmények száma és milyensége függvényében tíz-tizenöt szakembernél több biztosan nincsen. Például a legtöbb, azaz 54 intézményt fenntartó Egri Egyházmegyében 16 különböző végzettségű szakember (jogász, közgazdász, pedagógus) segíti az igazgatók mindennapi 
munkáját. Ma Magyarországon 1,7 millió gyerek van a közoktatásban, tehát óvodától érettségiig. Ebből 220000 az egyházi. Tehát közel másfél millió jár állami iskolába, és mindössze néhány százalék az alapítványi iskolák részesedése. A Katolikus Egyház, a szerzetesrendekkel együtt, 670 intézményt lát el, ez körülbelül 150000 gyerek.

\section{E: Teljesen elkülönülve kell elképzelni az egyházmegyéket?}

PI: Nem, rendszeresen találkoznak. A püspöki karhoz kötődő, országos Katolikus Pedagógiai Intézet fogja össze az egyházmegyék és a szerzetesrendek oktatással foglalkozó szakembereit. Rendszeresen publikálnak, közösen alakítják ki, akár alulról jövő vélemények figyelembevételével is, hogy a következő években a különböző oktatási kérdésekben hogyan tudjanak egységesen gondolkodni, cselekedni. Úgy gondolom, hogy ez a rendszer bevált. Ugyanezt csinálja egyébként Papp Kornél a reformátusoknál az Abonyi utcában, vagy csinálta korábban Mihályi Zoltánné az Evangélikus Egyháznál. A katolikusok most már óvatosabbak, illetve az önkormányzatok se nagyon kezdeményeznek.

\section{E: Mit ért azon, hogy óvatosabbak lettek?}

PI: Van már elég iskolájuk. Talán az óvodai ellátásban várható növekedés. Természetesen soha nem akarták az 1948-as, államosítás előtti arányt elérni. Akkor a népoktatás kb. 70\%-át a felekezetek látták el.

E: Vannak számitások, hogy mi lenne a reális az iskolafenntartó egybázak esetében?

PI: Olyan 15-20 \% körül. Mára már majdnem elérték ezt a számot, lassan ennyi az összes, egyházi iskolába járó diákok aránya. Új fenntartónak számítanak a baptisták. Illetve van a pünkösdi egyháznak, az adventistáknak, a krisna tudatú hívőknek, a buddhistáknak is egy-két oktatási intézményük. Ezen belül kb. 60-65\% katolikus és szerzetesrendi közoktatási intézményük lehet.

\section{E: Ez a 20\% forog katolikus berkekben is, vagy ez az Ön véleménye?}

PI: Ez az én véleményem. Amennyire ismerem a katolikus iskolák fenntartóit, ma már egyik sem kezdeményez új iskolaépítést vagy iskolaátvételt. Az más kérdés, hogy ha iskolai közösségek vagy önkormányzatok kezdeményeznek valahol helyben, akkor arra ők hogyan reagálnak.

\section{E: Készültek felmérések, bogy bol érdemes átvenni iskolát?}

PI: A demográfiát természetesen mindenki nézi. Más kérdés, hogy az 5000 főnél kisebb településeken az iskola megszüntetése hogyan járult hozzá az elnéptelenedéshez. Az iskola olyan értékek hordozója, megtartója, ami elengedhetetlen a helyi szellemiség vagy hagyomány továbbviteléhez. Amikor a politika elhatározta, de aztán nem hajtotta végre, hogy minden településen, gyerekszámtól függetlenül, legyen óvoda és alsó tagozatos iskola, akkor én azt mondtam, hogy végre, akkor megmenekülnek a kistelepülések.

E: Elég sok település van, ahol 2011, 2012 után az egyetlen iskola lett egyházivá. Hogyan ált hozzá az egyház az ilyen megkeresésekhez?

PI: Eleinte ódzkodtak, mert nem akartak feszültséget. Később megváltozott a helyzet, nagyon sok település azért fordult az egyházhoz, hogy megmaradjon az iskola. Ráadásul az önkormányzat akkor is magáénak érzi az iskolát, ha az egyházi fenntartású. Meg- 
marad tulajdonosnak, az egyház számára inkább partner. Elméletileg lehettek volna feszültségek, de ezeket megelözték.

E: Tudjuk, hogy azokban az iskolákban, amelyeket átvett a Katolikus Egybáz, a pedagógusok zöme maradt. Sokan közülük, ha nem a többség, nem gyakorló katolikus. Ez problémát jelenthet az egyháznak, tudjuk, pedagógushiány van, lecserélni nem tudja öket, még ha akarná, akkor sem.

PI: Természetesen a katolikus szellemiség megjelenik ezekben az iskolákban, az oktatásban, de nem biztos, hogy pont egy adott fizikatanárnak kell hívő katolikusnak lennie. Attól még lehet jó tanár. Tehát az egyház azt mondja, hogy nem az az érdekes, hogy milyen vallású a tanár. Jó pedagógus kell, aki lehetőleg ne csak oktasson, hanem a szakmája és a gyerekek szeretete hassa át a munkáját. Ha más vallású gyerek jár oda, akkor annak a hitoktatását is megszervezik ugyanúgy, mint a sajátjukat.

E: Sokszor elhangzik, bogy az egybázi iskolák egyre inkább a szegregáció irányában mozdulnak. Ezt még, ha jól tudom, Beer Miklós is elismerte. Erröl mit gondol?

PI: Nemrég jártam Felsőzsolcán. Az ottani Szent István Katolikus Általános Iskola száz százalékban cigány iskola. A településen van egy másik iskola, egy református, ott meg nincs cigány. Tehát a szülők eldöntik, hová viszik a gyereket, és hová nem.

E: Visszatérve a szegregációra, ezt sokan azzal is magyarázzák, hogy az egyházi iskolák jobban felszereltek, gyakoriak a felújitások, tehát mintha ténylegesen több pénzt kapnának az egybázi fenntartók, mint a tankerületek.

PI: Tudom, sokszor hallani, hogy bezzeg az egyházi iskolák a három-, négyszeresét kapják, de ez nem igaz. Illetve, ha igaz, akkor az állam az általa fenntartott intézményeket sanyargatja, illetve az általa ellátott kb. másfél millió gyerek oktatásához szükséges pénzt nem adja oda, míg az egyházi intézményekben járó kb. kétszázhúszezernek az 1997-ben megkötött Szentszéki megállapodás alapján köteles biztosítani azok finanszírozását, ahol az egyházi kiegészítő normatívát az előző évi, egy gyerekre jutó öszszegből számítják ki. Néhány évvel ezelőtt megszületett a KLIK, és egy fenntartás alá kerültek a különböző intézmények. Gyakorlatilag ezek az intézmények ki vannak szolgáltatva. A KLIK kapott pénzt, de nem annyit, amennyi szükséges lett volna az összes iskola ellátásához, egy év múlva aztán konszolidálni is kellett kb. 35 milliárddal. Ha normatív finanszírozásban gondolkodunk, akkor majdnem tízféle különböző normatíva létezik. Én úgy tudom, hogy az állam megállapodott az egyházakkal, hogy ők a normatívának egy átlagösszegét kapják, és abból gazdálkodnak. És akkor egy egyházmegye eldöntheti, hogy most itt vagy ott indítok egy óvodai csoportot, igaz, most még nem tudom, hogy mennyibe fog kerülni, de képes leszek biztosítani a feltételeit. Ha ugyanezt csinálhatnák a tankerületek is, ott se lenne gond. A katolikusok egyházmegyénként kapják meg a pénzt, és úgy osztják el. Náluk az nem fordulhat elő, hogy nincs pénz WC-papírra, vagy azt külön kellene kérni. Az intézmények élén munkáltatói és önálló gazdálkodási jogkörrel rendelkező igazgató biztosítja az oktatás-neveléshez szükséges feltételeket. De az állami iskolákban mit tehet az igazgatói jogkörrel nem rendelkező intézményvezető? Kap bizonyos ellátmányt. De ellátmányból hogyan lehet egy iskolát fenntartani? 
E: A tankönyvekkel kapcsolatban számomra nem világos a belyzet, mindenfélét hallani. Minden egybáznak lehet saját tankönyve?

PI: Nem, ők is csak válogathatnak a listán szereplő tankönyvekből, kivéve a hitoktatáshoz szükséges könyveket.

E: Azt látni, hogy az utóbbi időben nagyon megerősödött az egyházak jelenléte a szakképzésben. Ez egy teljesen új feladat számukra. Hogy birkóznak meg vele?

PI: Az a helyzet, hogy pontosan tudják, hogy a szakképzésben rengeteg hiányszakma van, és úgy gondolják, hogy esetleg segíthetnek. Megvan a szakértelmük, megvannak a szakoktatóik. Gondolok például a szalézi rend kazincbarcikai szakképző iskolájára, vagy a ferences rend jászberényi szakiskolájára, vagy a piarista rend gödi szakiskolájára, de nővérképzésben is részt vesznek.

E: Mindenesetre, úgy tünik, hogy manapság az egybázi iskoláknak „jól megy”, élvezik a nagypolitika támogatását.

PI: Az állam feladata a szektorsemlegesség biztosítása. Nemcsak gesztusokat kell tenni, hanem egyenlő elbírálást kell alkalmazni, az egyenlő feltételeket megteremteni. Nem kedvenceket kiemelni, támogatni, jogállamban nem lehet szelektálni. Az más, hogy felkérhetem az egyházakat, hogy segítsenek, mondjuk, a szociális gondoskodásban, az elesettek gondozásában. Amihez ilyen és ilyen feltételeket tudok biztosítani. Fontos azonban, hogy a párbeszéd mindig az emberekért folyjon. Jelenleg egy alá-fölé rendeltség alakult ki. Nem szerencsés az a fajta kegygyakorlás, ami viszonzást igényel. Meg kellene végre teremteni az államtól független, egyházi önálló gazdálkodás jogi és gyakorlati feltételeit.

E: Köszönöm szépen a beszélgetést!

$A z$ interjút Tomasz Gábor készitette.

\section{Interjú Papp Kornéllal, az MRE Zsinati Oktatási Iroda vezetőjével}

Educatio (a továbbiakban E): Kérem, mutatkozzon be!

Papp Kornél (a továbbiakban PK): Magyar-történelem szakos középiskolai tanár vagyok, 1990-ben végeztem az ELTE-n. Akkor indult a pedagógusi pályám, amikor az egyházi iskolák. Mindössze egy évet dolgoztam az állami szektorban, a Fazekas Gimnáziumban, utána már csak egyházi iskolában. 1995-2003 között a Református Pedagógiai Intézet igazgatóhelyettesi teendőit láttam el. Nekem jutott az a szép feladat, hogy megszervezzem a református pedagógiai-szakmai szolgáltatásokat. 1999-ben felkérést kaptam a Magyarországi Református Egyház Zsinati Iskolaügyi Oszztályának - mai nevén Oktatási Irodájának - a vezetésére, melyet tehát immár 20 éve látok el. Emellett 19 éve a Bocskai István Református Oktatási Központ intézményvezetőjeként is tevékenykedem. 
E: Az Oktatási Irodában folytatjuk a beszélgetést, az Abonyi utcában. Kérem, mondjon nébány szót az intézményröl.

PK: A református iskolák újjászerveződése 1989-ben kezdődött, akkor kapta vissza az evangélikus egyház a Fasori Gimnáziumot, idén van ennek a 30. évfordulója. Amikor már több közoktatási intézmény létrejött, az MRE Zsinata hozta létre 1992-ben az intézmények munkájának támogatására a Zsinati Iroda Iskolaügyi Oszzályát. 1999. január 1-jén lettem az Iskolaügyi Osztály vezetője. 2004-ben, amikor a zsinati adminisztráció átszervezése történt, a Zsinati Irodából Zsinati Hivatal, az Iskolaügyi Osztályból pedig Oktatási Iroda lett. Azokat a szervezeti egységeket, amelyek a különböző közszolgálati feladatokkal összefüggő ágazatokat gondozzák, irodának nevezték el. Az egyházon belül működő önálló jogi személyiséget 2019. január 1-jén kapta meg az MRE Zsinati Oktatási Iroda.

E: Olvastam a Református Egyház Köznevelési Törvényét, ahol részletesen le vannak írva az Iroda feladatai. Amennyire látom, egyfajta köztes szerepe van az Irodának a Zsinat és az intézmények között. Megtenné, hogy röviden beszél arról, hogy konkrétan mit csinálnak, milyen munkákat végeznek?

PK: Az oktatásüggyel összefüggésben négy terület gondozása tartozik hozzánk: mai kifejezéssel élve, a köznevelés, a hittanoktatás, a felsőoktatás és a felnőttképzés. Gyakorlatilag a négy területből egyedül a felnőttképzés területén nem sikerült eddig eredményt felmutatni. A felsőoktatás területén inkább csak koordináló szerepünk van, információkat gyüjtünk, illetve osztunk meg, egyrészt az intézményekkel, másrészt az egyház vezetésével, mintegy hidat képezve. A Református Egyház kebelén belül négy felsőoktatási intézmény működik, ebből három egyházkerületi, egy pedig - a Károli Gáspár Református Egyetem - zsinati, tehát közegyházi fenntartásban. A közvetlen ügyeiket, például az egyetemi tanári kinevezéseket, a rektorok kinevezését a fenntartóikon, tehát az egyházkerületeken, illetve a Zsinat elnökségén keresztül intézik, az Oktatási Irodának ebben nincsen szerepe. Nekünk akkor van feladatunk, amikor például valamilyen hitéleti szaknak az elindításáról van szó. De menjünk át a köznevelésre. A hit- és erkölcstan kérdése 2013 óta nagyon érinti a köznevelést, de nem az egyházi köznevelési intézményeket, hanem az államiakat, szóval itt a legerősebb az Oktatási Iroda funkciója, ugyanis az összes hittanoktatót itt foglalkoztatjuk. Ez kb. 320 munkavállalót s mintegy 1400 egyéb foglalkoztatottat jelent. Havonta 1700 foglalkoztatottnak utaljuk át a munkabért vagy a megbízási díjat, s társadalombiztosítási kifizetőhelyként teljes körűen látjuk el a társadalombiztosításukat. Mintegy 140-150 ezren részesülnek református hittanoktatásban, több mint a felük állami iskolákban tanul. A református köznevelési intézményekbe mintegy 52 ezer növendék jár, köztük sok a nem református gyermek, tanuló. A református intézmények mindig is befogadóak voltak. A katolikus és az evangélikus egyház mellett a baptista egyház is végez intézményeinkben hittanoktatást. Mintegy 38 ezer főre tehető a református intézményekben a református hittanoktatásban részesülők száma.

E: Itt az irodában egyébként hányan dolgoznak? Mi a feladata az irodának a köznevelés területén?

PK: Jelenleg nyolcan. Hárman munkaügyesek, bérszámfejtők, társadalombiztosítási ügyintézők, hárman foglalkoznak az adatfeldolgozással, s egy kollégám az informatikai 
fejlesztéseket koordinálja. Mi a szerepe az irodának a köznevelés területén? Nyilvánvaló, hogy az egyik legfontosabb szerepe, hogy a belső egyházi döntéshozatalt készíti elö, illetve a döntések végrehajtását segíti: adatokat gyűjt, különböző alternatívákat vázol fel, a végrehajtást megtervezi, $\mathrm{s}$ arról folyamatosan beszámol. A döntések azonban nem itt születnek meg.

\section{E: Milyen ügyekre kell itt konkrétan gondolni?}

PK: A törvényünk elég általánosan fogalmaz, anyagi és szellemi ügyeket említ. Szellemi ügy lehet egyrészt hitélettel összefüggő és a belső szabályrendszer. El kell dönteni például, hogy egyáltalán ki alapíthat református köznevelési intézményt. Milyen eljárások után, ki kinek felel. Egy kerettanterv elfogadásánál vagy a tankönyvjegyzék esetében évről évre frissítenünk kell az Oktatási Hivatalnál, hogy a Református Egyház milyen tankönyveket ismer el hittankönyvnek. Az anyagi ügyek tekintetében az a legfontosabb, hogy a finanszírozás gyakorlatilag kétlépcsős (előleg, ill. egyenlegrendezés). Az első lépcső alapvetően két különböző elemből áll. A tárgyévben a református intézményfenntartók előleget kapnak, ennek az elszámolása a zárszámadási törvényben történik meg, és egy évvel később kerül sor az egyenlegrendezésre, amikor is megvizsgálják, hogy az állami szektorban a megelőző, lezárandó esztendőben mennyit költöttek egy tanulóra, és az egyházi intézmények tanulólétszáma után ezt az egy főre jutó átlagösszeget elszámolják az összlétszámra. Az előleg is két részből áll, az átlagbéralapú támogatásból és a müködési támogatásból. Az átlagbéralapú támogatást közvetlenül az intézményfenntartók kapják a Magyar Államkincstártól, a működési támogatást viszont közvetlenül a bevett egyház kapja meg. Ennek a lebontása és eljuttatása az intézményfenntartók számára az Oktatási Iroda feladata. Annak eldöntése, hogy ez mi alapján, milyen normatív összegek alapján történik, már nem ránk tartozik, azt a megfelelö szakmai előkészítések után, a Zsinat testülete hozza meg a költségvetés elfogadásakor. Tehát megint csak a végrehajtás történik az Oktatási Irodában.

\section{E: Teljesen egységesen, tanulói létszám után arányosan osztják el a pénzt?}

PK: Teljesen egységesen jut el a pénz, tehát normatív arányban. Az országos pedagógiaiszakmai szolgáltatások és a tanügyirányítás megszervezésének költségeire a fedezetet a müködési támogatás biztosítja. A Zsinat testülete fogadja el, hogy adott naptári évben ilyen célra mennyi fordítható. Amikor az egyházak, és köztük a Református Egyház, mint köznevelési intézményfenntartó egyház az állami féllel egyeztetéseket, tárgyalásokat folytat, amikor az állami jogszabálytervezetek társadalmi vitája zajlik, akkor ezeken szakértőként az Oktatási Iroda vezetője vesz részt.

\section{E: Milyen gyakran hívják meg Önöket?}

PK: A Kormány és a Magyarországi Református Egyház 1998. dec. 8-i megállapodása és az azóta módosított megállapodás is rögzíti, hogy minden olyan kérdésben egyeztetést szükséges tartani, amely érinti a Református Egyházat. Volt olyan időszak, amikor több alkalommal elmaradt az egyeztetés, amikor egy-egy törvénytervezet képviselői indítványként került a Parlament elé, de az is előfordult, hogy egyszerüen nem gondoltak arra, hogy a módosítás érinti az egyházakat. 
E: Emlitene egy példát? Melyik volt a legjelentösebb, Önöket leginkább érintö kérdés, amiböl igy kimaradtak?

PK: A szakképzésről szóló jogszabályok. A szakképzés területén 2015 februárja után csak 2019-ben történt egyeztetés az egyházakkal. Az illetékes minisztérium inkább belső jogi személyekkel, a fenntartókkal egyeztetett (ez pl. 7-8 fenntartót jelent a Református Egyház esetében). Úgy véljük, hogy az intézményfenntartók elsősorban csak a saját intézményükben folyó szakképzés hátterét ismerhetik, ily módon kisebb a rálátásuk a folyamatokra, mint az országos szakképzés problémáinak ismeretével az Oktatási Irodában. Az érdekeket mindig jobb egységesen képviselni. Bízunk abban, hogy a szakképzés területén is rendszeresek lesznek az egyeztetések.

A hittanoktatás és a felsőoktatás mellett a harmadik terület, amivel foglalkozunk, az a köznevelés, ideértve a szakképzés területét is. Egyfajta támogató szolgálatot biztosítunk az intézményfenntartóknak és az intézményeknek, amellyel munkájukat segítjük. Itt most nem pedagógiai-szakmai szolgáltatásra kell gondolni, arra ott vannak a pedagógiai intézetek, hanem közigazgatási tevékenységre. A köznevelési törvény konkrétan meghatározza, hogy mi egy intézmény hatásköre, mik a fenntartó jogai és kötelezettségei. De a köznevelési törvényben például nincs definiálva, hogy a fenntartó felett álló egyházi jogi személynek van-e bármiféle joga, jogosultsága beavatkozni egy intézmény életébe. Mi persze nem írhatunk elő semmit, nem avatkozhatunk bele a fenntartó-intézmény viszonyába, viszont közzétehetünk jó gyakorlatokat, dokumentumokat, konkrétan például, hogy mi az intézményvezetö-választás eljárásrendje, történjen akár pályázat, akár meghívás útján, hogy néz ki egy intézményvezetői megbízás szövege, hogy néz ki egy pályázat, hol és mikor kell kérni miniszteri egyetértést.

E: Ez azt jelenti, hogy az intézményvezetők választása nem egységes? Lehet pályázat vagy meghivás?

PK: Igen mindkettő létezik. Az állami szférában kötelező a pályáztatás, de nálunk a meghívás a gyakoribb. Természetesen minden olyan egyeztetési fórum, amit a jogszabály elöír, az nálunk is szerepel, például nemzetiségi önkormányzat, amennyiben egy iskolában nemzetiségi oktatás folyik. Ha egy református intézményben legalább öt osztály működik, a fenntartónak létre kell hoznia a fenntartói igazgatótanácsot. Ez a fenntartói igazgatás egy szerve, ahol elsősorban a köznevelés ügyéhez értő szakemberek találhatók, és ez az igazgatótanács az, amely a nevelőtestület véleményének a meghallgatása után javaslatot tesz a presbitérium, a döntéshozók számára, hogy egy adott személy meghívását javasolja. Az igazgatótanács javaslatára a presbitérium általában már igent tud mondani. Szintén az ilyen támogató-segítő, koordinációjellegű funkcióink közé sorolnám, ahogy a müködést is ellenőrizzük. Létrehoztunk egy eljárásrendet, ami gyakorlatilag egy monitoring. Az a feladat, hogy egy tanügyigazgatási szakember és egy pénzügyi szakember, meghatározott rend szerint, eljusson minden fenntartóhoz, és ott az állami támogatás jogszerü felhasználását ellenőrizze. Ez a monitoring kicsit tágabb feladatot jelent, mint egy hites könyvvizsgálat, amely utóbbit csak a törvényes felhasználás érdekli, mi ezzel szemben olyan észrevételeket is teszünk, hogy például hatékonyan vagy nem hatékonyan használták fel a forrásokat. Úgy, ahogy előbb az intézményvezetö-választással kapcsolatban említettem, e tekintetben is javaslatokat, észrevételeket teszünk a fenntartónak, és ezeket elküldjük a felettes egyházi hatóságnak is, jelen esetben a fenntartó egyházkerületnek. 
E: Másra terelném a szót. Elindult a változás a Fasori Gimnázium átvételével 1989-ben, azóta jelentösen bövült az egybázi iskolák hálózata. Közismert, hogy az egybázi iskolák száma leginkább 2011-ben és 2012-ben emelkedett. Egy törvényváltozásnak köszönhetően, amit az önkormányzatok kihasználtak, nagy számban adták át az önkormányzatok iskolájukat valamelyik egyháznak, illetve volt, aki elöremenekült, megérezvén a közelgö államositást. Fel volt erre a nagy rohamra készülve a Református Egyház? Hogyan oldották meg a feladatot, milyen problémák adódtak?

PK: Igen, ez a folyamat 2011-től 2014-ig tarthatott. 2013. január elsejével kerültek állami fenntartásba az önkormányzati intézmények. Gyakorlatilag azóta nincsen iskolaátvétel. Ezt az időszakot csak akkor tudjuk értékelni, hogyha egy pillantást vetünk az előttünk lévő esztendőkre. 2004-től az intézményátvételt folyamatosan próbálták ellehetetleníteni. Az elv mindig az volt, és a gyakorlatnak ezt kellett lekövetnie, hogy egy gyermek ugyanannyi támogatásban kell, hogy részesüljön - függetlenül attól, hogy állami vagy egyházi iskolába jár-e. Az egyenlegrendezés során az állami-önkormányzati szintre egészítik ki az egyházit, azt az előleget, amit az egyházak kapnak. Ezekben az előbb említett esztendőkben - 2005, 2006 és 2008-ról van szó - az elszámolás nem volt korrekt, a tényleges ráköltésnél kevesebbet állapítottak meg. 2007-ben volt egy állami számvevőszéki vizsgálat, ahol az előző két évet illetően ezt megállapították, és ezután jött még a 2008-as esztendő, ami 4 milliárd Ft állami tartozást jelentett. Ezt 2010 után az Orbán-kormány fizette ki az egyházaknak, két vagy három év alatt. Most visszatekintve azt tudom mondani, hogy ily módon az egyházak hozzájutottak ahhoz, ami az 1998-ban létrejött, Hornféle Vatikáni Megállapodás nyomán járt nekik. Az önkormányzatok számára mindezek ellenére az egyházi köznevelési intézmények finanszírozása kiszámíthatónak, stabilnak tünt. Ráadásul az egyházak nem felettük hozták meg döntéseiket.

E: Tehát azt állítja, hogy egy egybázi iskolába járó diák után nem jár több pénz, mint egy állami iskolába járóé után?

PK: Én azt mondom, hogy egy tárgyévben kevesebb jut, az elszámolással együtt pedig pont ugyannyi jut, mint az állami, önkormányzati szektor átlaga.

E: És ez jelenleg is így van?

PK: Jelenleg is. Csak mivel, például, most 2018 decemberében jutottunk hozzá a 2017. évi kiegészítéshez, ezt az összeget be tudjuk forgatni az idei, tehát 2019-es működési költségekbe. Így nem okoz működési zavart, hogy csak később kapjuk meg a pénzt. Ha nem korrekt az elszámolás, az viszont müködési zavart okoz.

E: Úgy véli, hogy ez az említett nem korrekt elszámolás kihatott az átvételekre is?

PK: 2004 környékén, amennyiben egy önkormányzat átadott egy intézményt, akkor két évig az önkormányzatnak kellett fizetni az egyházi kiegészítő támogatást. Emiatt sok önkormányzat úgy döntött, hogy akkor inkább megszünteti az intézményét, viszont ugyanabban az épületben és még ugyanabban az évben induljon ott egy egyházi iskola. $\mathrm{A} z$ állam ezt persze meg akarta akadályozni, úgyhogy emiatt kimondták, hogy amenynyiben a megszüntetés és az újjáalapítás között kevesebb mint három hónap telik el, és a tanulók több mint 50\%-a megegyezik, akkor azt úgy kell tekinteni, mintha egyszerü átadás-átvétel történt volna. Ezzel gyakorlatilag megszüntették az egyházi átvétel lehetőségét. Emellett hivatalosan leírták, hogy „az általános iskolának nyolc évfolyama van”. 
Ezzel a jogszabállyal viszont minden alulról felfelé építkező egyházi iskolaalapítást kizártak a lehetséges opciók közül. Gyakorlatilag megakadályozták az önkormányzatokat abban, hogy az anyagi ellehetetlenülésük elől úgy meneküljenek el, hogy az intézményüket átadják egy egyháznak.

\section{E: Ez változott meg drámaian 2011-ben.}

PK: Megváltozott, és teljesen váratlanul, mondhatni felkészületlenül ért bennünket. Az önkormányzatok 2012-ben, de már 2011-ben is tudták, hogy az állam át fogja venni a fenntartói jogokat, tehermentesíteni fogják anyagi tekintetben az önkormányzatokat. Viszont sokaknak félelme volt, és akkor itt megint csak a 2000-es évek elejére kell viszszagondolni, hogy hány helyen történt intézménybezárás, hány helyen szüntettek meg iskolát pénzügyi okokból, vagy vitték el egyik településről a másikra a felső tagozatot. Ettől féltek az önkormányzatok, hogy az állam ugyanazt a racionalizálást fogja megvalósítani, mint a 2000-es években, és lehetséges, hogy pont az ő településükön fog megszűnni iskola. És mivel azt is tudták, hogy az egyháznak van mozgástere, hogy nekik például nem írják elő, hány fővel indulhat egy első osztály, azt a meggyőződést érlelte ki bennük, hogy akkor marad meg az iskola, ha átadják valamelyik egyháznak.

E: Mik voltak a Református Egybáz szempontjai ezeknél az átvételeknél? Minek alapján döntötték el, hogy átvesznek-e egy adott iskolát, avagy sem?

PK: A Magyarországi Református Egyház inkább fékezni szerette volna ezt a folyamatot. Egyházunk felépítése más, mint a többié. A belső egyházi jogi személyiséget a helyi közösségeink is megkapták, vagyis, ha helyi szinten egy önkormányzat megkeresett egy egyházközséget, akkor az intézményátadást, -átvételt gyakorlatilag magukban le tudták bonyolítani. Szükség volt azonban az egyházkerület elnökségének az egyetértésére, nekünk pedig minden esetben meg kellett vizsgálnunk, hogy az adott egyházi személy alkalmas-e arra, hogy intézményfenntartó legyen. Ha egy egyházközségnek elmaradásai voltak, nem tudott egy költségvetést összeállítani, ha lehetett látni, hogy személyi összetételét tekintve sok konfliktus várható, akkor nem lehet egy intézmény ügyeit rábízni egy ilyen fenntartóra.

E: A demográfiai adatokat megnézték, a gyerekszámok feltételezhető alakulását, hogy mennyi esélye van egy adott településen annak, hogy az iskola fennmaradhat?

PK: Ha a fenntartó el tudta látni a szerepét, akkor minden esetben megvizsgáltuk a népesedési adatokat is. Az egyházkerületekben müködnie kell egy oktatási szervezetnek, egy ugyanilyen oktatási irodának, mint itt, csak kisebbnek. Két egyházkerületünkben ez nagyon profi módon müködik, az egyik a tiszáninneni, a másik a tiszántúli. Ott ezeket a vizsgálatokat helyben el tudják végezni. A többi esetben pedig a Zsinati Oktatási Irodához szokták irányítani a fenntartó aspiránsokat. Emellett meg szoktuk nézni a nevelőtestület összetételét, korfáját. Egy alacsony gyereklétszám és egy idős nevelőtestület gyakorlatilag fenntarthatatlanná tesz egy intézményt.

\section{E: Felekezeti hovatartozást is néztek?}

PK: A tantestületnél nem. Viszont a felekezeti hovatartozásnál azt szoktuk vizsgálni, hogy miért fontos az egyházközség úgynevezett missziója szempontjából az, hogy neki legyen iskolája. Tehát azzal, hogy a településen lesz egy református iskola, azzal jobban 
tud-e kommunikálni a helyi társadalommal, vagy nem? Ha van például egy gyenge református közösség, kevés hívővel, a település többsége más vallású, akkor nincs értelme átvenni az iskolát. Ha viszont egy településen egyensúlyban vannak a felekezetek, sőt a többi felekezet is jónak látja, hogy a Református Egyház vállalja fel a felekezeti oktatás lehetőségét, akkor ebben látunk fantáziát, mert gyakorlatilag a társegyházakat is meg lehet szólítani, nekik is fontos, hogy legyen katolikus vagy evangélikus hittanoktatás az adott iskolában, és nyilván ők is tudnak kommunikálni az intézményen keresztül a szülőkkel.

E: Nemcsak iskolákat vett át a Református Egyház, hanem pedagógusokat is, köztük olyan embereket, akiknek esetleg semmilyen elkötelezettségük nincs a református egybáz iránt. Ez nem szült problémákat?

PK: Megint csak azt tudom mondani, hogy a feladatunknak, a küldetésünknek az időbeli távlatait kell látni. Ha 2011-ben átveszünk egy intézményt, akkor nem azt a célt kell kitűznünk, hogy 2013-ban ott egy olyan református iskola müködjön, mint a Debreceni Református Kollégium. 29 éve vannak újraalakult intézmények, egyik sincs még abban a helyzetben, mint a Debreceni Református Kollégium, ahol folyamatos volt az élet. Természetesen rövid távon, ami lehet harmincvalahány év is, arra kell törekedni, hogy az oktatás-nevelés ügyét ott a helyi közösségben minél szakszerübben lássuk el. Ezt próbáljuk azzal kiegészíteni, hogy felmutatunk egy értékrendet, ezt próbáljuk hitelesen képviselni a diákok és a pedagógusok előtt. Az, hogy azok a pedagógusok eddig nem láttak bennünket, nem érzékeltek bennünket, esetleg nem voltak keresztyének, nem jelenti azt, hogy nincs meg az a lehetőség, hogy tudatosan döntsenek emellett. Csak a saját intézményemből is tudok példát arra, hogy olyan kollégák járnak el rendszeresen templomba, még nyári szünidőben is, akik korábban nem láttak belülről templomot. Számunkra, missziónk szempontjából ez egy pozitív dolog.

\section{E: Van azért valamiféle elvárás?}

PK: Különböző helyeken más és más elvárásokat fogalmaznak meg. Akiket átvettünk, azokra azok a szabályok érvényesek, amelyek az átvétel pillanatában voltak. Például nem kötelező a hit- és erkölcstan azoknak a gyerekeknek, akik az állami iskola tanulói voltak. Akik már tudatosan az egyházi iskolába iratkoznak be, nekik kötelező valamelyik hit- és erkölcstan, református, katolikus, evangélikus, vagy akár a baptista bibliaismeret. A pedagógusok számára az elvárásokat a különböző helyeken különbözőképpen fogalmazzák meg. Saját iskolámban, akkor, amikor már az összes diák egyházi beiskolázású volt, azt kértük a diákoktól, hogy havonta egy alkalommal, saját településükön, saját felekezetük szerint látogassák a templomot. Ez évente 9-10 templomlátogatást jelent. Aztán megfogalmaztuk azt, hogy ha a diákokkal szemben vannak ilyen elvárásaink, akkor ugyanezt nekünk, pedagógusoknak is teljesítenünk kellene. Ez azonban nem vonatkozik azokra a kollégákra, akik már az átvételkor is az iskolában dolgoztak, csak azokra, akik később érkeztek hozzánk. Azt vettem észre, hogy a régi kollégák közül is egyedül a földrajzi szempont volt akadályozó tényező, ha túl messze van a lakóhelye, akkor ott helyben jár vasárnap istentiszteletre. Ahol türelmetlenül nyúlnak bele, és azt mondják, hogy akkor most tanév végéig tessék megkeresztelkedni, az nem szül jó vért, de ilyenről nem is nagyon hallani. A pedagógusok rutinból hozták azokat a gyakorlatokat, amiket még az állami iskolában alkalmaztak. A '90-es években és 2000-es évek 
elején induló iskoláknál természetes volt, nekünk nem kellett új tantervet készítenünk, hanem a meglévő állami kerettantervbe tudtuk bevinni az egyházi tartalmat. Olyasmikre gondolok, mint például hogyan lehet az egyháztörténetet bevinni a történelemoktatásba. Ezeket sokkal nehezebb az újonnan átvett iskolák pedagógusaival megértetni. Most egy nagy tananyagfejlesztő munkában vagyunk. Digitális tananyagot szeretnénk fejleszteni minél több tantárgyra és minél több évfolyamra, azt remélve, hogy ezeket a pedagógusok majd beépítik az óráikba. A '90-es években ez még csak írott formában történt, ma már az a leghatékonyabb, ha digitális tananyagot fejlesztünk. Ezen dolgozik jelenleg Pompor Zoltán csapata.

E: Én azt hittem, hogy az egyházaknak, köztük a Református Egyháznak, külön tankönyveik is lesznek. Akkor ez nincs így?

PK: Ez tényleg felmerült, viszont ha csak azt nézzük, hogy hány tanulója van egy-egy évfolyamon az egyházaknak, akkor nyilvánvaló, hogy csak nagyon gazdaságtalanul lehetne ezeket a tankönyveket kiadni. Arról nem is beszélve, hogy milyen sürün változnak a tartalmi szabályozók. Ha egy tankönyvet készítünk, ahhoz el kell készíteni a kerettantervet, mert azzal együtt lehet a tankönyvet akkreditáltatni. Világnézetileg elkötelezett tantervet állami iskola nem használhat. Viszont azokat a digitális tananyagokat, amelyeket mi fejlesztünk, meggyőződése vagy szakmai érdeklődése alapján nyugodtan választhatja egy állami iskolában dolgozó kolléga. Ugyanúgy, ahogy mi is választunk az állami vagy magánfelületeken található segédanyagokból, mint amilyen például az OFI fejlesztette Nemzeti Köznevelési Portál vagy a Tankocka.

\section{E: Külön kerettantervük tehát nincs?}

PK: Nincs, és soha nem is volt. Viszont mintatantervet adtunk ki általános iskoláknak, hogy hogyan lehet a kerettantervbe beépíteni az egyházi tartalmat.

\section{E: Tudna mondani oktatási ügyeket, ahol egybázon kívül és belül viták zajlottak?}

PK: Tartalmi kérdésekről nagyon éles vitákat folytattak a magyar oktatáspolitika alakítói a '90-es évektől a 2000-es évek közepéig, azóta ezek már nem olyan élesek. A pedagógusok belefásultak ebbe a kultúrharcba. Úgyis azt tanítanak, amit akarnak, illetve a lehetőségeiket a tankönyv határozza meg. Jelenleg egy nagy munkában vagyunk. A református oktatási stratégiát próbáljuk kidolgozni. Egy évtizeddel ezelőtt már végiggondoltuk, de ugye azóta történt egy nagy átalakulás. Ebben a stratégiában tíz területet, tíz pillért azonosítottunk, és ezek mentén próbálunk akcióterveket kidolgozni. Azt gondolom, hogy ez az, ami a mi belső vitánknak nevezhető.

\section{E: Személy szerint kik vesznek részt a munkában?}

PK: A munkák már legalább két éve folynak, van egy koordinátor és egy ötfös csapatunk, melyet Ábrám Tibor, a tiszáninneni fögondnok vezet. Benne van az Oktatási Iroda vezetője, vagyis én, aztán a Református Pedagógiai Intézet vezetője, Szontagh Pál, a tiszántúli tanügyi tanácsos, dr. Veress Bertalan, és végül a fenntartók képviseletében a mezőtúri lelkész, Mihalina László. A pillérek beazonosítása után mindegyikre egy bizottságot hoztunk létre. Első körben az adott célhoz vezető út meghatározása történt, az építőkövek felállításán dolgoztunk. Ezt a munkát már lezártuk, mára már beazonosítottuk a közvetlen, rövid távú feladatokat, és most ezekhez készülnek az akciótervek. 
E: Köztudott, hogy a szakképzésben az egyházak korábban nemigen voltak jelen. Ez a belyzet az utóbbi időben megváltozni látszik. Úgy tünik, mintha a magániskolák kiszorulásával keletkezett ürt az egybázi intézmények kezdenék betölteni. Mit gondol erröl?

PK: A Református Egyháznak minimális volt a részvétele a szakképzésben 2011 előtt. Ennek az oka alapvetően az volt, hogy az államosítás előtt, egy-két polgári iskolán kívül, nem voltak ilyen intézményeink. Nem voltak öregdiákjaink, akik verték volna az asztalt, hogy kérjük vissza az iskolát. Előfordult persze, hogy olyan iskolát vettünk át, amely az állami időszakban a gimnáziumi mellett szakközépiskolai képzést is folytatott. Ilyen volt például Mezőtúr. Gimnáziumként került át, és gimnázium-szakközépiskolaként jött vissza. Így lett tehát szakképzésünk, öt vagy hat intézményünk lehetett a 2000-es évek elején. Nem volt felemelő dolog szakképző iskolát fenntartani, mert pangott a gazdaság, ellenben gyarapodott a gimnáziumi férőhelyek száma, olyannyira, hogy azok is be tudtak jutni gimnáziumba, akik nem akartak később felsőfokon továbbtanulni. Emiatt létszámproblémák keletkeztek a szakiskolákban. Például, abban az iskolában, amit én vezetek, 2 év alatt (1999-2001) lecsökkent a létszám 400-ról 260 före. A mezőgazdasági szakképzés különösen válságban volt. Emellett ezekbe az intézményekbe jellemzően nagyobb arányban jártak nehezen kezelhető, sajátos nevelési igényü, tanulási és beilleszkedési zavarral küzdő gyerekek. Miért akarna valaki ilyen intézményt? Egyre többen hangoztattuk ugyanakkor, hogy az egyház gyakorlatilag egy rezervátumba zárja magát, ha nem nyit, és nem létesít szakképző iskolákat. Ehhez azonban, a gyakorlóhelyek miatt, sokkal nagyobb forrásra volt szükség. Önerőből az egyházak nem tudtak elindítani szakképző iskolákat. Így az egyházak számára kapóra jött, hogy a megyei és városi önkormányzatok bezárás helyett intézményüket inkább megpróbálták „átpasszolni”. Bezárás helyett legyen inkább az egyházé. Ez nekünk is jól jött, hiszen ezek az intézmények egy ürt töltöttek ki. Persze volt olyan iskola, amellyel nem boldogultunk. Főleg amiatt nem, mert a tankötelezettséget levitték 18-ról 16 éves korra. Volt olyan iskolánk, ahová jellemzően roma fiatalok jártak, és ők 16 éves koruk után eltűntek az iskolából. A mezőcsáti iskolát azért kellett visszaadnunk állami fenntartásba, mert fenntarthatatlanná vált a tanulói létszám csökkenése miatt. A sárospataki Vayiban is nagyon csökkent a létszám, kevesebb mint a felére az átvétel óta. Az elmúlt években azért kikristályosodott, hogy ennek ellenére van egy-két olyan szakképzési intézményünk, ahol megfelelő szakértelemü és szakképzettségű pedagógusok dolgoznak, ahol a szakmák olyanok, hogy elegen jelentkeznek rájuk, megoldott tehát a létszám. A tárgyi feltételek is rendelkezésre állnak. Ezeket a helyeket tudjuk fejleszteni, ha kell, a szakképzési repertoáron is tudunk változtatni, és egy karakteresebb református szakképzést tudunk megvalósítani. Igen ám, de azzal, hogy a szakképzés átkerült az NGM-be, majd az ITM-be, és megjelent az a teória, hogy a létszámot és a képzési struktúrát a gazdaság igényeihez kell igazítani, az állam meg akarja mondani, hogy az egyes ágazatokban, szakmákban hány főt képezhetünk. Ahhoz, hogy mi működni tudjunk, nemcsak alapító okiratra van szükségünk, hanem müködési engedélyt is kell kérnünk. Utóbbinál fel kell mutatni a személyi és tárgyi feltételeket, és föleg az ingatlan nagysága alapján mondják meg, hány fö vehet részt az adott képzésben. 2013-ban bevezették az ún. szakmaszerkezeti döntést, és ebben elkezdték azt a létszámot csökkenteni, amire mi amúgy az államtól a működési engedély révén lehetőséget kaptunk. Most azt mondja az állam, hogy müködési engedély ide vagy oda, én nem vagyok hajlandó azt a létszámot finanszírozni, hanem csak ezt a létszámot. Önmagában ez még nem is lenne probléma, ha valamiféle elveket alkalmaznának, például 
azt mondanák, hogy ti kevesen vagytok, az állami rendszer nagy, hajlandók vagyunk nálatok biztosítani a létszámokat, akár az állami rovására. A nagy egészben úgysem számít, hogy öttel több vagy kevesebb lesz az asztalos. Ezzel szemben az a szemlélet jelent meg, először az agrártárcánál, hogy én csak akkor engedélyezem nekik a létszámot, ha magam nem tudom ellátni a feladatot. Ez az ún. maradékelv. És valóban, először az alapítványi iskolák létszámait „húzták le”. Hozzáteszem, az agrártárcánál évek óta már az egyháziakat is. És mivel, ahogy korábban jeleztem, négy évig nem volt találkozó az állam és az egyházak között a szakképzés témakörében, az volt a félelmünk, hogy ez a maradékelv megjelenik az ITM-ben, s ezáltal mi csak arra kapunk majd lehetőséget, amit a szakképzési centrum nem tud ellátni. Nincs vegyipari képzés épp Kazincbarcikán, a reformátusban van, oké, megadjuk. De ha informatikusról van szó, azt mi el tudjuk végezni, ti nem indíthattok ilyen képzést.

\section{E: Múlt idöt használt, szóval itt változott valami?}

PK: Most változik minden jogszabály.

\section{E: Bevonták Önöket a tervezési fázisba?}

PK: Nem. Én kaptam meghívót a Szakképzési Innovációs Tanács nevezetü fórumra, ahol legalább harminc különböző területről érkező szakember van jelen. Itt érdemi munkát nem lehet végezni, gyakorlatilag tájékoztatásokat hallgatunk meg. Nekem nem az Audival van vitám, vagy a MOL-lal, meg nem is a Nemzeti Pedagógus Karral. Az én problémáim kizárólag az állami félre és az egyházakra tartoznak. Nem is értik ott, amit el akarok mondani, én sem azt, amit ők. Engem nem érint, hogy a tanulószerződés hogyan alakul át munkaszerződéssé. Ez fontos kérdés az Audiban, de nálam kevésbé. Ha a törvényt módosítják, akkor megszűnik a szakmaszerkezeti döntés maga, mint rendelet, helyette hároméves megállapodást köthetnek a fenntartók a miniszterrel. Igaz, eddig is a miniszter meg a kormány döntött, de most olyan helyzet áll elö, hogy egy fenntartó, akár egy helyi egyházközség lelkipásztora, és a miniszter állapodik meg arról, hogy hány informatikus lehet, hány rendész, asztalos, kertész stb. Én csak reménykedni tudok abban, hogy ez a maradékelv nem uralkodik el. Ami az agrárképzésben van, azt már sajnos nehéz visszahozni. Nálunk konkrétan a kertészet és parképítési szakgimnáziumi képzést irtották ki, nem kaptunk keretszámot. 1971 óta kertészeti iskola volt az intézményünk. Csak olyan képzést tudunk folytatni, amit engednek. Szerencsére van gimnázium, két gimnáziumi osztályt indítok, 68 helyre 190 jelentkezőm van. A szakgimnáziumban, miután nem engedték a kertészetet, elindítottuk a rendészeti és közszolgálati képzést, van emellett informatika és ügyvitel. A szakközépiskolából még megmaradt a virágkötő, dísznövénykertész és a számítógép-kezelö. De ezzel a három szakmával is alig tudok összehozni egy osztályra valónyi gyereket.

E: Sokat hallottam most az egyházi intézmények hátrányairól. Hol, miben látja az elönyeiket? Az már elhangzott, hogy nincsenek létszámboz kötve az osztályindítások, mik még?

PK: Azt is már mondtam, hogy nálunk rugalmasabban lehet döntéseket hozni, mivel azokat helyben hozzák, és nem egy tankerületben. Továbbá az, hogy a gazdálkodás az intézményben folyik, tehát nem összevontan egy centrumban. Ugyanez mondható el a pedagógiai innováció tekintetében is. 
E: Úgy hallottam, hogy most az óvodák felé is elkezdenek nyitni az egybázak. A katolikusoknál is, Önöknél is.

PK: Igen, erre a nagy állami óvodafejlesztés keretében kerül sor. Az elsők már idén megkezdik a müködésüket, de ezek jellemzően átvett intézmények. Az építőipar szárnyalása jelentősen akadályozza, késlelteti a program végrehajtását, gondolok itt a jelentős áremelkedésekre, vagy arra, mennyire felmentek az ingatlanárak.

E: Még egy utolsó kérdésem lenne. Hogyan látja, beállt az állami-egyházi közötti arány, vagy még további módosulás, az egyházi diákok arányának növekedése várható? Egyáltalán mit tartana ideálisnak?

PK: Én úgy gondolom, hogy az óvodák kivételével beállt. Az, hogy az óvodafejlesztési programnak pontosan mi lesz az eredménye, egyelőre nem látható, ez a következő 2-3 évben fog kiderülni. Említettem, hogy a 2000-es évek elején évente 5-6 intézmény jött létre, 2011 után volt egy fellendülés, ez mára mérséklődött. Idén úgy néz ki, hogy két iskolával gyarapodunk, viszont egyet visszaadunk az államnak. A statisztikákat mindig felborítják az intézményi összevonások. Mi inkább azt támogatjuk, hogy ne mindenki akarjon önálló lenni, jobb, ha komplexebb intézmények jönnek létre.

E: Inkább egyházmegye, mint egyházközség?

PK: Nem, a fenntartó lehet egyházközség, de tagintézményei legyenek. Ne kelljen 2-3 gazdasági hivatalt müködtetni, hanem csak egyet. A fejlesztési forrásokat így lehet optimalizálni.

E: Köszönöm a beszélgetést.

Az interjút Tomasz Gábor készitette.

\section{Interjú Varga Mártával, a Magyarországi Evangélikus Egyház Nevelési és Oktatási Osztályának vezetőjével}

Educatio (a továbbiakban E): Kérem, hogy röviden mutatkozzon be olvasóinknak!

Varga Márta (a továbbiakban VM): 2011 óta vagyok a Magyarországi Evangélikus Egyház Nevelési és Oktatási osztályának vezetője. Korábban intézményvezetőként dolgoztam önkormányzati fenntartású iskolákban. 10 évig vezettem a VII. kerületi Janikovszky Éva Általános Iskola és Gimnáziumot. Gyógypedagógusi és középiskolai tanári végzettségem van. Az evangélikus nevelési és oktatási rendszerben végzett szakmai munkám meghatározó területei: intézményi innováció, szervezetfejlesztés, oktatásirányítás, vezetői munka támogatása.

E: Összesen hány intézmény tartozik ma a Magyarországi Evangélikus Egybázhoz?

VM: Most kb. 19 ezer gyermek jár a köznevelési intézményeinkbe. 15 gimnázium, 5 szakgimnázium, 10 kollégium, 21 általános iskola, 6 alapfokú művészeti iskola és 33 óvoda tartozik hozzánk. A felsőoktatásban az Evangélikus Hittudományi Egyetem (EHE), 
3 felsőoktatási szakkollégium, ebből két roma szakkollégium működik a Magyarországi Evangélikus Egyház fenntartásában. A felsőoktatási és köznevelési intézmények szakmai munkájának támogatását az Evangélikus Pedagógiai Szakmai Szolgáltató és Továbbképző Intézet (Evangélikus Pedagógiai Intézet - EPSZTI) végzi. Jelenleg nincs egységes gyógypedagógiai módszertani intézményünk, pedig nagy szükség lenne rá a rendszerünkben.

E: Ha az evangélikus iskolahálózatról van szó, önkéntelenül az jut az eszembe, különösen oktatástörténészként, hogy 1945 elött ez egy "túlfejlesztett” iskolabálózat volt: nagyobb kínálattal rendelkezett, mint amekkora igény az evangélikus közösség részéröl felmerült, így sok nem evangélikus diákot is be tudott fogadni. Ez a fajta nyitottság ma is jellemzö az evangélikus iskolákra?

VM: 1989-től kerültek újra a Magyarországi Evangélikus Egyházhoz oktatási intézmények, elsőként a Fasori Evangélikus Gimnázium. Az előző negyven évben nem rendelkeztünk semmilyen oktatási intézménnyel. A fenntartói háttértámogatást, az oktatásirányítást is lépésről lépésre kellett felépítenünk. Elsősorban a hagyományok, az érzelmi kötődés motiválták azt, hogy egyes állami vagy önkormányzati intézmények a Magyar Evangélikus Egyházhoz kerültek. Azokon a helyeken történt főleg átvétel, ahol egy gimnázium működött erős gyülekezeti háttérrel, ez adta azt az érzelmi kötődést, ami az átvételhez vezetett. Nem egy tudatos intézményhálózat-fejlesztés jellemezte tehát az első 15-20 évet, ami meg is látszik az intézményhálózaton. Nagyon kevés a szakképző intézményünk, ezért nehezen tudjuk megszólítani azokat, akik a szakképzésbe szeretnének bekapcsolódni. Ezért a Zsinat 2017-es döntése alapján az átvételek, alapítások során előnyben részesítjük az óvodákat és a szakképző intézményeket. Ami a területi elhelyezkedést illeti, meglehetősen szórt a hálózatunk, Nyíregyházától Sopronig, Miskolctól Bonyhádig vannak köznevelési intézményeink. A helyi kezdeményezés, szükséglet, lehetőségek meghatározóbbak voltak, mint a területi lefedettség biztosítása. Viszont az a fajta befogadó jelleg, felekezeti sokszínűség, ami korábban jellemző volt az evangélikus iskolákra, jelenleg is fontos érték számunkra. Nagyon különbözö intézményenként, hogy az evangélikusok aránya hogyan jelenik meg. A más egyházhoz tartozó gyerekek saját felekezetük szerinti hitoktatásban részesülnek, az áhítatok, egyházi alkalmak, ünnepek szolgálatába gyakran vesznek részt más felekezetü lelkészek, papok.

\section{E: Milyen problémákat jelent, ha egy egyháznak túl sok gimnáziuma, elitiskolája van?}

VM: A Magyarországi Evangélikus Egyház arra törekszik, hogy a missziós küldetését tudja teljesíteni. Ha jelentős társadalmi csoportoknál, mint pl. a roma családok vagy a hátrányos helyzetűek, nem tudunk megjelenni, akkor annak nincs jó üzenete. A saját gyülekezeteink felé is nehéz kommunikálni, hogy miért maradnak ki a rendszerből a legrászorultabbak. Volt egy kutatás, amely kimutatta, hogy a Magyarországi Evangélikus Egyházban a legmagasabb a nyolcosztályos gimnáziumok száma. Erre nekünk is figyelnünk kell, ezt az arányt csökkenteni szeretnénk. Még akkor is, ha emögött semmilyen szegregációs szándék nem volt, csupán az a történeti körülmény, hogy elsősorban érzelmi kötődések alapján vettünk át intézményeket. 
E: Mint emlitette, ezek többnyire iskolaátvételek voltak, amiben az érzelmi szempontok elég fontos szerepet játszottak. Volt olyan megkeresés is, amikor egy intézmény saját maga kérte, hogy a Magyarországi Evangélikus Egyház vegye át?

VM: A KLIK előtti években nagyon sok ilyen megkeresés volt. Polgármesterek, önkormányzati vezetők úgy vélekedtek, hogy az egyháznál talán nagyobb biztonságban van a település óvodája, iskolája. Mi óvatosan fogadtuk ezeket a megkereséseket. Van egy szigorú szempontrendszerünk, hogy mi alapján veszünk át egy intézményt. Az újságírókat ez nagyon érdekelte abban az időszakban, mert felmerült, hogy ebben van valamilyen kontrollálatlanság. Ez azonban nem így van: mivel minden átvételt az oktatási bizottság és a gazdasági bizottság vizsgál, a helyi gyülekezetnek kell véleményeznie, most még hozzájön a nyilatkoztatás a szülők, pedagógusok részéről, azután az Országos Presbitérium dönt, és végül az EMMI bólint rá. Tehát nagyon komoly szürőn megy át minden ilyen döntés. Mi már elég korai szakaszban megpróbáljuk kiszürni azt, ami nem megvalósítható. Ezért több szempontból vizsgáljuk a megkereséseket: milyenek a személyi feltételek, mennyire fenntartható financiálisan az intézmény, milyen az iskola pedagógiai programja, mennyire összeegyeztethető a keresztény nevelési elvekkel. Vizsgáljuk a település mutatóit, a demográfiai adatokat, mert a fenntarthatóság is kiemelt szempont. Azért nem veszünk át intézményt, hogy két év múlva bezárásra kerüljön. $\mathrm{S}$ ami még nagyon fontos, hogy van-e evangélikus vezető. Ez nálunk súlyos feltétel, mert ha a vezető idegenkedik, nem ismeri az evangélikus értékeket, akkor nehéz helyzetben vagyunk, mert csak lelkészekkel nem tudjuk ezt a küldetést véghezvinni.

\section{E: Volt olyan is, hogy egy intézményt visszautasitottak?}

VM: Igen, sok ilyen eset volt. Származtak ebből nehézségek, kommunikációs problémák. Az elmúlt nyolc év tapasztalata alapján úgy látom, hogy jó döntéseket hozott a Magyarországi Evangélikus Egyház az átvételek során.

\section{E: Milyen feszültséggel járt az, ha teljes apparátussal kellett átvenni egy-egy intézményt?}

VM: Most már a pedagógusok és a szülők is nyilatkoznak arról, hogy szeretnék-e az átvételt. A mi álláspontunk mindig is az volt, hogy nem elég ehhez az $50+1 \%$. Ha nincs közös elszánás ebben, nem látható az elköteleződés, akkor nincs értelme. Szembemenni az iskolát működtetők és használók akaratával, értelmetlen. Talán ennek tudható be, hogy az átvételeknél komoly konfliktusaink nem voltak.

E: Emlitette, hogy a fenntarthatóság kiemelt szempont, és a rendszerben csak bizonyos irányú bövitésekben gondolkodnak. A bálózatfejlesztésben milyen prioritások lesznek a következö években a meghatározóak?

VM: A budapesti agglomerációban vannak erős gyülekezeteink, ahonnan az óvoda hiányzik. Említettem a középiskolai expanziót, amelyhez társul ez a nagyon komoly igény, hogy legyen általános iskola, óvoda. Ezen felül van még néhány erős gyülekezet, ahol egyáltalán nincs intézményünk, mint pl. Zalaegerszegen vagy Székesfehérváron. Ezeken a helyeken is szóba került új intézmények indítása, de itt is elsősorban az óvoda. Prioritás a saját rendszerünk minőségi fejlesztése. Ennek érdekében olyan innovációkat indítottunk el, amelyek közül már látszik néhánynak az eredménye, pl. a kompetenciamérés eredményeinek a javítására, a pedagógiai módszerek megújítására az Expanzió oktatáskutatóival végzünk egy közös fejlesztést. Az első öt intézmény projektje éppen most zá- 
rul. Volt egy kutatás az ELTE-vel és az Evangélikus Hittudományi Egyetemmel közösen is, amit a rendszerünkben tanuló evangélikus diákok hitéleti megélésével kapcsolatban végeztünk el. Arra voltunk kíváncsiak, hogy milyen hatással van a középiskolai diákok hitmegélésére a család, a környezet, az intézmény. Elkezdtünk egy tantervfejlesztést, ahol olyan evangélikus tantervi elemeket szeretnénk kidolgozni, amelyeket a szabadon felhasználható órakeret terhére magyarból és énekből használhatnak fel a pedagógusok. Ennek nagyon jó volt a visszhangja a pedagógusok körében. Erősítjük még az iskolai lelkészi hálózatot. Minden, háromszáz feletti létszámú intézményben független iskolalelkész tevékenykedik. Ez a legnagyobb kihívás a lelkészeknek és az intézményeknek is, ezért nagyon fontos, hogy őket is tudjuk támogatni képzésekkel.

E: Ön a Nevelési és Oktatási Osztály vezetöje. Hogyan kell elképzelnünk ennek a bivatalnak a müködését? Mennyire centralizált az oktatásirányitás?

VM: A szervezetünk egy gazdasági csoportból, egy erős titkárságból és egy pedagógiai intézetből áll, ami teljes létszámmal müködik már öt éve, kiváló és sokoldalú szakemberekkel. Hiába kicsi a rendszer, ha sokféle iskolatípus van, sok mindenhez kell érteni: a statisztikákhoz, a nyilvános vagy vezetői kommunikációhoz, a marketinghez stb. Nálunk két típusú fenntartói rendszer van: gyülekezeti fenntartás és országos fenntartás. A gyülekezeti fenntartású intézmények többnyire az óvodák. Véleményem szerint az óvodai fenntartói feladatokat a helyi gyülekezet vezetői - a mi támogatásunkkal kiválóan el tudják látni. Az osztályunk a szakmai iránymutatást végzi. Tulajdonképpen a Nevelési és Oktatási Bizottság az, ami az előkészítő javaslataink alapján szakmai döntéseket hoz, és véleményezi az intézmények pedagógiai programját, az alapdokumentumait, a vezetői pályázatát, a költségvetését, a beszámolóját. Utóbbiak mennek a Gazdasági Bizottságra is, a végső döntést pedig a gyülekezeti intézmények esetében a helyi presbitériumok hozzák meg, az országos fenntartásúak esetében pedig az országos presbitérium. Úgy látom, hogy a gyülekezeti fenntartókkal ki tudtunk alakítani egy szoros bizalmi és szakmai kapcsolatot. Akkor is kikérik sokszor a véleményünket (pl. egy szülői panaszos ügyben), amikor nekünk nincs jogosultságunk, de érzik, hogy itt egy olyan szakmai stáb dolgozik, akikkel érdemes együttműködniük. Mi is örülünk annak, hogy az iskolavezetők igénybe veszik ezt a lehetőséget, és ezzel elkerülik a komolyabb konfliktusokat. A kulcsa a „centralizált, de mégsem” müködésnek az, hogy a vezetőink önállóan gazdálkodhatnak, és ha a pedagógiai programban valamilyen változtatást akarnak, azt önállóan kezdeményezhetik. Akár nagy beruházásokat is tervezhetnek saját hatáskörben, mert az Építési Osztály szakmai tudásával támogatja, a Gazdasági Bizottság elmondja a véleményét, és ha úgy ítélik meg, hogy megvalósítható, akkor mehet. Az esetek többségében ez így célba is talál. Ezért is koncentrálunk annyira a vezetők kiválasztására.

\section{E: Milyen konkrét feladatokat lát el a Pedagógiai Intézet?}

VM: Az Evangélikus Pedagógiai Intézet, az EPSZTI, állami jogszabály alapján müködik. Szakmailag szolgáltatást végeznek, van egy szolgáltatói kosár, vannak képzések, vannak konferenciák és egy erős tantárgygondozói hálózat. Fontos, hogy a tantárgygondozók összefogják az egy tantárgycsoportot tanító kollégákat, találkoznak velük rendszeresen, közös honlapjuk van, kommunikációs hálózatban működnek, ahogyan a szaktanácsadói rendszer is. Össze szoktuk hívni a minősítő kollégákat, mert az is fontos, hogy bejöjje- 
nek információk a rendszerből. A Pedagógiai Intézet komoly szerepet vállal a döntéselőkészítésben, pl. az átvételek esetében is fontos, hogy legyen egy olyan szakmai vélemény, ami a létszámokat, a pedagógiai programot, a beágyazottságot, az esetleges kockázatokat be tudja mutatni. Nekünk az a dolgunk, hogy jó döntéseket tudjon hozni az országos presbitérium vagy a helyi fenntartó.

$\mathrm{A} z$ Erasmus+ keretében felvidéki és erdélyi intézményekkel partnerségben 300 nagyon elesett helyzetű családdal kerültünk kapcsolatba, a program eredményeként pedig egy kézikönyvet adtunk ki, amely módszertani gyüjtemény, a gyakorlati munkát kívánja segíteni.

A fejlesztések közül fontos a digitális stratégiára alapozott digitális fejlesztés, amihez részben eszközöket, részben képzéseket csatoltunk, illetve minden intézmény elkészítette a digitális névjegyét és a helyi digitális fejlesztési programját. Ezt az állami projekt mintájára hoztuk létre, de sokat gyötrődtünk vele. Ez is olyan terület, ahol külső szakembereket kell behívnunk.

Van egy ösztöndíjas programunk az oktatásvezetői szakvizsga támogatására, szerződünk azokkal a kollégákkal, akiket tehetséges vezetőnek látunk. Belső vezetői értékelési rendszert müködtetünk, minden intézményvezető kétévente visszajelzést kap a munkájáról. Továbbképzésekkel, közösségépítő alkalmakkal segítjük vezetőinket. Fokozatosan csökken a plenáris elöadások száma, és átveszi helyét a tapasztalatcsere, a szakmai mühely. Müködtetünk egy vezetői támogató rendszert, amiben bárki ingyen igénybe vehet szupervíziót, csoportos tréninget, coachot, lelki vezetést. Vannak olyan vezetői mühelyeink, amelyek egy speciális csoportot érintenek, mint pl. a szakképzési mühely. Nálunk a vezetőknél van a kulcs, és a mi dolgunk az, hogy támogassuk őket, amivel csak tudjuk.

E: A vezetöknél már érintettük az autonómia kérdését. Hogyan néz ki ez az oktatásirányitás felöl és az állammal való kapcsolatban? Mennyiben tud autonóm tanügyigazgatást megvalósitani az egybáz? Miben tud önállóbban dönteni, gondolok itt akár programok, a kerettantervek, a tananyag-, tankönyvfejlesztésekre, akár a pedagógusok bérezésére vagy a különbözö szolgáltatások biztositására?

VM: A vezetők kiválasztásába az államnak nincs beleszólása, viszont a jóváhagyás esetében a törvényes feltételek meglétét vizsgálja. Mi törekszünk arra, hogy betartsuk a törvényeket. Nyilván van humánerőforrás problémája a Magyarországi Evangélikus Egyháznak is. Mi nem gondoljuk, hogy önállóan szeretnénk kerettantervet engedélyeztetni, nincs rá kapacitásunk, és itt az átmenet kérdése is felmerül. Most van egy fejlesztésünk Kőszegen, ami egy alternatív iskolai müködést fog megvalósítani, elsősorban a módszerekben, és látható, hogy az állami keretek is adnak annyi mozgásteret, hogy - ha a pedagógusok felkészültek erre, és tudnak például projektekben tanítani, használják a korszerü pedagógiai módszereket - akkor ez nem gát.

E: Lenne igényük arra, bogy saját tankönyveket fejlesszenek ki?

VM: Arra lenne inkább igényünk, hogy legyen tankönyvpiac, de a kerettantervhez kapcsolódóan a pedagógusaink egy része képes önállóan is tanulást segítő anyagok kidolgozására, digitális tananyagok létrehozására. Meggyőződésem, hogy ez lehet a jövő útja. 
E: A Magyarországi Evangélikus Egybázon belüli irányzatok mennyire hatnak ki a tanügyigazgatásra, vannak-e ezzel kapcsolatos belsö viták, nézetbeli különbségek?

VM: Nálunk nincs tanítói hivatal, központi állásfoglalás arról, hogy kinek mit kell gondolnia egyes konkrét kérdésekben. Nagyon fontos, hogy mindenki meg tudja élni a maga hitét úgy, ahogyan ő gondolja. Az iskoláknál ez azért nem okoz gondot, mert az iskolák területileg meghatározottak, a helyi lelkésznek a gyülekezettel van napi kapcsolata, és ez határozza meg alapvetően az intézmény irányultságát.

E: A többi egyházi iskoláboz képest miben tér el az evangélikus iskolák arculata, pedagógiája? VM: Az iskolák belső életére nálunk jellemző, hogy az evangélikusok vannak kisebbségben. Nincs olyan iskola, ahol 100\%-ban vagy $90 \%$-ban evangélikusok lennének a diákok, ezért az ökumené nagyobb szerepet kap. A már hivatkozott hitéleti kutatást megelőzte egy pedagógiai tartalomkutatás, amelyben arra voltunk kíváncsiak, hogy a diákok vagy a pedagógusok mit gondolnak az iskoláinkról. Ebben kijöttek a „családiasság”, a „személyre szabottság”, a „szabadság”, a „különbözőség elfogadása” mint értékek.

E: Mennyire érzik a versenyt, mennyire tudják megállni a belyüket az evangélikus iskolák? Szó volt a kompetenciamérésekröl. Ebben milyen eredményeket értek el?

VM: A kompetenciamérés azért fontos, mert a hozzáadott érték fontos a számunkra. Ez ezért hangsúlyosabb. Büszkék vagyunk arra, hogy a Deák téri a legjobb egyházi iskola, és arra, hogy több intézményünk is felkerült a legjobbak listájára. Hozzáadott érték szempontjából nagyon sok olyan intézményünk van a rendszerben, akik kemény munkát végeznek és komoly eredményeket értek el.

E: Utolsó kérdésnek hagytam azt, amiröl mostanában a legtöbbet lebet olvasni az egyházi iskolákkal összefüggésben...

VM: A finanszírozás...

E: Igen, látjuk a számokat, hogy milyen szorzója van az egybázi iskolákban a fejkvótának, és lehet, hogy ez az igazságérzetünket sérti, de valójában nem erre szeretnék rákérdezni, hanem arra, hogy ez a többletforrás mire forditódik az evangélikus iskolák esetében?

VM: Erröl írtunk egy feljegyzést, és az a tervem, hogy minden évben ki fogunk adni egy beszámolót, hogy hogyan áll az evangélikus oktatás. Ebben a kérdésben úgy látom, hogy van egy általános félreértés. Nehéz megérteni a jogszabályi hivatkozások nélkül, hogy $\mathrm{mi}$ is a helyzet, ezért ezt szívesen átküldöm. ${ }^{1}$ A lényege ennek, hogy az egy gyerekre jutó pénz ugyanannyi az egyházi iskolákban, mint az államiakban. A különbség annyi, hogy ezt az összeget az egyház mint fenntartó megkapja, és ebből a saját döntése alapján továbbítja az intézményeknek a finanszírozásukhoz szükséges támogatást. A béreken felüli

1 2011. évi CCVI. törvény 19. § (1) A jogi személyiséggel rendelkező vallási közösség részére a közcélú tevékenységek ellátásához az állam költségvetési támogatást nyújt. (2) A bevett egyház és belső egyházi jogi személye az általa vagy intézménye útján ellátott közcélú tevékenysége után a hasonló tevékenységet folytató állami vagy helyi önkormányzati intézményekkel azonos mértékü költségvetési támogatásra jogosult. A bejegyzett egyház, a nyilvántartásba vett egyház és ezek belső egyházi jogi személyei az általuk vagy intézményeik útján ellátott közcélú tevékenységük után - erre vonatkozó megállapodás alapján legfeljebb a hasonló tevékenységet folytató állami vagy helyi önkormányzati intézményekkel azonos mértékủ költségvetési támogatásra jogosultak. A megállapodás megkötésénél figyelembe kell venni a 9. § (1) bekezdésében foglalt feltételeket. 
részre mi minden évben csak előleget kapunk, majd minden év végén elszámol az állam az egyházakkal, és fillérre ugyanannyit kapunk, mint amennyit az állam egy gyerekre költ. Az egyház dönt arról, hogy a stratégiai céloknak megfelelően milyen fejlesztéseket támogat, mennyit költ oktatásirányításra, szolgáltatásokra. Belső pályázatokat ír ki, gondoskodik az épületek fenntartásáról. A sajátos működtetési rendszerből fakadóan lehetnek eltérések az állami és az egyházi intézményfinanszírozás között. Ha egy intézménynél maradvány keletkezik, azzal az intézmény gazdálkodik. Vagyis: a pénz felhasználásában van különbség, nem az állami finanszírozás mértékében.

Ez a finanszírozási rend, a jelenlegi jogszabályok alapján azt jelenti, hogy az egyházi fenntartású intézmények azonos mértékben részesülnek az állami forrásokból, mint az állami, önkormányzati fenntartású oktatási intézmények. Ez garantálja számunkra az evangélikus oktatási rendszer biztonságos, színvonalas és törvényes müködtetését.

E: Köszönöm szépen a beszélgetést.

Az interjút Biró Zsuzsanna Hanna készitette.

A cikk a Creative Commons Attribution 4.0 International License (https://creativecommons.org/licenses/ by/4.0/) feltételei szerint publikált Open Access közlemény, melynek szellemében a cikk bármilyen médiumban szabadon felhasználható, megosztható és újraközölhető, feltéve, hogy az eredeti szerző és a közlés helye, illetve a CC License linkje és az esetlegesen végrehajtott módosítások feltüntetésre kerülnek. (SID_1) 